\title{
Physiologically based pharmacokinetic modeling of zinc oxide nanoparticles and zinc nitrate in mice
}

This article was published in the following Dove Press journal:

International Journal of Nanomedicine

5 October 2015

Number of times this article has been viewed

\author{
Wei-Yu Chen' \\ Yi-Hsien Cheng ${ }^{2}$ \\ Nan-Hung Hsieh ${ }^{3}$ \\ Bo-Chun $\mathrm{Wu}^{2}$ \\ Wei-Chun $\mathrm{Chou}^{4}$ \\ Chia-Chi $\mathrm{Ho}^{4}$ \\ Jen-Kun Chen ${ }^{5}$ \\ Chung-Min Liao,** \\ Pinpin $\operatorname{Lin}^{4, *}$ \\ 'Department of Biomedical Science \\ and Environmental Biology, Kaohsiung \\ Medical University, Kaohsiung, \\ ${ }^{2}$ Department of Bioenvironmental \\ Systems Engineering, National \\ Taiwan University, Taipei, ${ }^{3}$ Institute \\ of Labor, Occupational Safety and \\ Health, Ministry of Labor, New \\ Taipei City, ${ }^{4}$ National Institute of \\ Environmental Health Sciences, \\ ${ }^{5}$ Institute of Biomedical Engineering \\ and Nanomedicine, National Health \\ Research Institutes, Zhunan, Taiwan \\ *These authors contributed equally \\ to this work
}

\begin{abstract}
Zinc oxide nanoparticles ( $\mathrm{ZnO} N \mathrm{NP}$ ) have been widely used in consumer products, therapeutic agents, and drug delivery systems. However, the fate and behavior of ZnO NPs in living organisms are not well described. The purpose of this study was to develop a physiologically based pharmacokinetic model to describe the dynamic interactions of ${ }^{65} \mathrm{ZnO}$ NPs in mice. We estimated key physicochemical parameters of partition coefficients and excretion or elimination rates, based on our previously published data quantifying the biodistributions of $10 \mathrm{~nm}$ and $71 \mathrm{~nm}{ }^{65} \mathrm{ZnO}$ NPs and zinc nitrate $\left({ }^{65} \mathrm{Zn}\left(\mathrm{NO}_{3}\right)_{2}\right)$ in various mice tissues. The time-dependent partition coefficients and excretion or elimination rates were used to construct our physiologically based pharmacokinetic model. In general, tissue partition coefficients of ${ }^{65} \mathrm{ZnO}$ NPs were greater than those of ${ }^{65} \mathrm{Zn}\left(\mathrm{NO}_{3}\right)_{2}$, particularly the lung partition coefficient of $10 \mathrm{~nm}{ }^{65} \mathrm{ZnO}$ NPs. Sensitivity analysis revealed that $71 \mathrm{~nm}{ }^{65} \mathrm{ZnO}$ NPs and ${ }^{65} \mathrm{Zn}\left(\mathrm{NO}_{3}\right)_{2}$ were sensitive to excretion and elimination rates in the liver and gastrointestinal tract. Although the partition coefficient of the brain was relative low, it increased time-dependently for ${ }^{65} \mathrm{ZnO}$ NPs and ${ }^{65} \mathrm{Zn}\left(\mathrm{NO}_{3}\right)_{2}$. The simulation of ${ }^{65} \mathrm{Zn}\left(\mathrm{NO}_{3}\right)_{2}$ was well fitted with the experimental data. However, replacing partition coefficients of ${ }^{65} \mathrm{ZnO}$ NPs with those of ${ }^{65} \mathrm{Zn}\left(\mathrm{NO}_{3}\right)_{2}$ after day 7 greatly improved the fitness of simulation, suggesting that $\mathrm{ZnO}$ NPs might decompose to zinc ion after day 7. In this study, we successfully established a potentially predictive dynamic model for slowly decomposed NPs. More caution is suggested for exposure to ${ }^{65} \mathrm{ZnO} N P s<10 \mathrm{~nm}$ because those small ${ }^{65} \mathrm{ZnO}$ NPs tend to accumulate in the body for a relatively longer time than $71 \mathrm{~nm}{ }^{65} \mathrm{ZnO}$ NPs and ${ }^{65} \mathrm{Zn}\left(\mathrm{NO}_{3}\right)_{2}$ do.
\end{abstract}

Keywords: zinc nanomaterials, bioaccumulation, biodistribution, PBPK modeling, partition coefficient

\section{Introduction}

Nanomaterials have a broad range of applications in technology and biological medicine because of the unique properties of nanoparticles (NPs), which render nanomaterials convenient and efficient for use. However, the increasing use of engineered NPs has led to increased exposure potential and concern for human and environmental safety. NPs can enter an organism through various pathways and distribute systemically in the circulatory and lymphatic systems and ultimately into tissues. ${ }^{1}$ The biodistribution of NPs might markedly influence their biological effects in vivo, such as in inflammatory and oxidative responses related to cardiopulmonary toxicity. ${ }^{2,3}$

Zinc oxide nanoparticles ( $\mathrm{ZnO}$ NPs) are commonly used in sunscreens in particle sizes ranging from $70 \mathrm{~nm}$ to $100 \mathrm{~nm}$ because of strong ultraviolet absorptive properties. ZnO NPs also have potential application in the delivery of therapeutic agents for tumors and autoimmune diseases. ${ }^{4-6}$

In our previous study, we reported the biodistribution of ${ }^{65} \mathrm{ZnO}$ NPs in mice. ${ }^{7}$ The results provide relevant data for developing a particle size-dependent physiologically 
based pharmacokinetic (PBPK) model for metal NPs. The advantages of a PBPK model include the ability to integrate the physiological structures of organisms and the physicochemical properties of toxicants and provide quantitative descriptions of the kinetic processes of absorption, distribution, metabolism, and excretion. ${ }^{8}$ A PBPK model is an effective tool to estimate the time course of chemical accumulation in target tissues of organisms and can be incorporated into a quantitative risk assessment framework. The dynamic interactions of NPs in living organisms, such as transportation kinetics across biobarriers, can also be described by a metal NP-based PBPK model. A nanometal PBPK model with adequate predictive power can be used to investigate mechanical processes, evaluate hypotheses, and guide experimental designs and also has advantages of reduced animal testing and costs and the ability to simulate and predict biodistribution in humans and the human response to NPs. ${ }^{9}$

Therefore, in this study, we aimed to develop an appropriate particle size-dependent PBPK model for describing ${ }^{65} \mathrm{ZnO}$ NP pharmacokinetics in mice and to evaluate the tissue accumulation properties of various ${ }^{65} \mathrm{ZnO}$ NP sizes and zinc nitrate $\left({ }^{65} \mathrm{Zn}\left(\mathrm{NO}_{3}\right)_{2}\right)$. We identified that physicochemical parameters of $10 \mathrm{~nm}$ and $71 \mathrm{~nm}{ }^{65} \mathrm{ZnO}$ NPs and ${ }^{65} \mathrm{Zn}\left(\mathrm{NO}_{3}\right)_{2}$ in NP PBPK modeling were predictive of ${ }^{65} \mathrm{ZnO}$ NP biodistribution and accumulative levels in living organisms. Our PBPK model was able to predict the distributions of ${ }^{65} \mathrm{ZnO}$ NPs and ${ }^{65} \mathrm{Zn}\left(\mathrm{NO}_{3}\right)_{2}$ in target tissues.

\section{Materials and methods}

All animal treatments and experimental protocols for this study were reviewed and approved by the Institutional Animal Care and Use Committee of the National Health Research Institutes (NHRI), Zhunan, Taiwan.

\section{Test NPs}

ZnO NPs of $71 \mathrm{~nm}$ diameter were purchased from Alfa Aesar (Ward Hill, MA, USA), while ZnO NPs of $10 \mathrm{~nm}$ diameter were purchased from NanoScale Corporation (Manhattan, $\mathrm{KS}, \mathrm{USA})$. $\mathrm{Zn}\left(\mathrm{NO}_{3}\right)_{2}$ was purchased from Showa Corporation (Tokyo, Japan). Radioactive ${ }^{65} \mathrm{ZnO}$ NPs and ${ }^{65} \mathrm{Zn}\left(\mathrm{NO}_{3}\right)_{2}$ were generated using the Tsing Hua Open-Pool Reactor (THOR; National Tsing Hua University, HsinChu, Taiwan). Before neutron activation, the surface area, surface charge, shape, and size distribution of cold $\mathrm{ZnO}$ NPs were assessed and reported in the previously published paper. ${ }^{7}$

For surface chemistry identification, ZnO NPs were subjected to Raman spectroscopic analysis using DXR Raman Microscope (DXR; Thermo Fisher Scientific, Waltham, MA, USA) with DXR $532 \mathrm{~nm}$ laser and full-range grating $\left(50-3,500 \mathrm{~cm}^{-1}\right)$. For crystalline analysis, each sample ( $1 \mathrm{~g}$ ) was filled into a sample holder and subjected to X-ray powder diffraction. The measurements were carried out by powder X-ray diffraction (MiniFlex II, Rigaku Corporation, Tokyo, Japan) with a scan speed of $2^{\circ}$ per minute for the scan angle between $10^{\circ}$ and $90^{\circ}$. Figure $\mathrm{S} 1 \mathrm{~A}$ and $\mathrm{B}$ are Raman spectra of $10 \mathrm{~nm}$ and $71 \mathrm{~nm} \mathrm{ZnO}$ NPs, respectively, in which the characteristic $\mathrm{Zn}-\mathrm{O}$ stretching bands are observed at $436 \mathrm{~cm}^{-1}$ and both NPs are not chemically modified on their surface. ${ }^{10}$ Figure S2A and B display X-ray diffraction patterns of $10 \mathrm{~nm}$ and $71 \mathrm{~nm} \mathrm{ZnO} \mathrm{NPs,} \mathrm{respectively,} \mathrm{present-}$ ing no significant difference between these two NPs. The diffraction peaks for $10 \mathrm{~nm} \mathrm{ZnO}$ NPs are located at $31.62^{\circ}$, $34.30^{\circ}, 36.12^{\circ}, 47.42^{\circ}, 56.46^{\circ}, 62.84^{\circ}, 65.32^{\circ}, 67.84^{\circ}$, and $69.00^{\circ}$. The diffraction peaks for $71 \mathrm{~nm} \mathrm{ZnO} \mathrm{NPs} \mathrm{are} \mathrm{located}$ at $31.44^{\circ}, 34.10^{\circ}, 35.92^{\circ}, 47.24^{\circ}, 56.28^{\circ}, 62.54^{\circ}, 65.12^{\circ}$, $67.64^{\circ}$, and $68.78^{\circ}$. These X-ray diffraction patterns are assigned to (100), (002), (101), (102), (110), (103), (200), (112), and (201) planes of hexagonal wurtzite crystal of $\mathrm{ZnO}$, which are in good agreement with data published by Talam et al and Uysala et al. ${ }^{11,12}$

\section{Study data}

Using previously published tissue accumulation data from mice injected with ${ }^{65} \mathrm{ZnO}$ NPs and ${ }^{65} \mathrm{Zn}\left(\mathrm{NO}_{3}\right)_{2}$, the sizedependent ${ }^{65} \mathrm{ZnO} \mathrm{NP}$ and ${ }^{65} \mathrm{Zn}\left(\mathrm{NO}_{3}\right)_{2}$ PBPK mice model were constructed. ${ }^{7}$ The experiments provided information on tissue burdens that enabled intravenously injected ${ }^{65} \mathrm{ZnO}$ NPs and ${ }^{65} \mathrm{Zn}\left(\mathrm{NO}_{3}\right)_{2}$ to be compared. Before neutron activation, the surface area, surface charge, shape, and size distribution of cold $\mathrm{ZnO}$ NPs were assessed and reported in the previously published paper. ${ }^{7}$

To evaluate the accumulation of $10 \mathrm{~nm}$ and $71 \mathrm{~nm}{ }^{65} \mathrm{ZnO}$ NPs and ${ }^{65} \mathrm{Zn}\left(\mathrm{NO}_{3}\right)_{2}, 120 \mu \mathrm{g}$ of suspended ${ }^{65} \mathrm{ZnO}$ NPs or ${ }^{65} \mathrm{Zn}\left(\mathrm{NO}_{3}\right)_{2}$ were dissolved in $400 \mu \mathrm{L}$ of distilled water and injected into 6-week-old male ICR mice (0.031-0.032 kg) through a tail vein. ${ }^{7}$ The sampling times for accumulation and tissue weight measurements were 1, 2, 4, and 7 hours and 1, 2, 3,7 , and 28 days postinjection. The tissue samples included blood, liver, lung, kidney, spleen, brain, heart, gastrointestinal (GI) tract, and carcass (muscle and bone).

\section{Model construction}

Figure 1 shows the study framework and computational algorithm. The prototypical mice PBPK model for ${ }^{65} \mathrm{ZnO}$ NPs and ${ }^{65} \mathrm{Zn}\left(\mathrm{NO}_{3}\right)_{2}$ (Figure 2) were established based on the key assumptions that 1) a chemical is well mixed and homogeneously distributed within each compartment, 2) all transport within blood and tissues is limited by the flow circulatory 


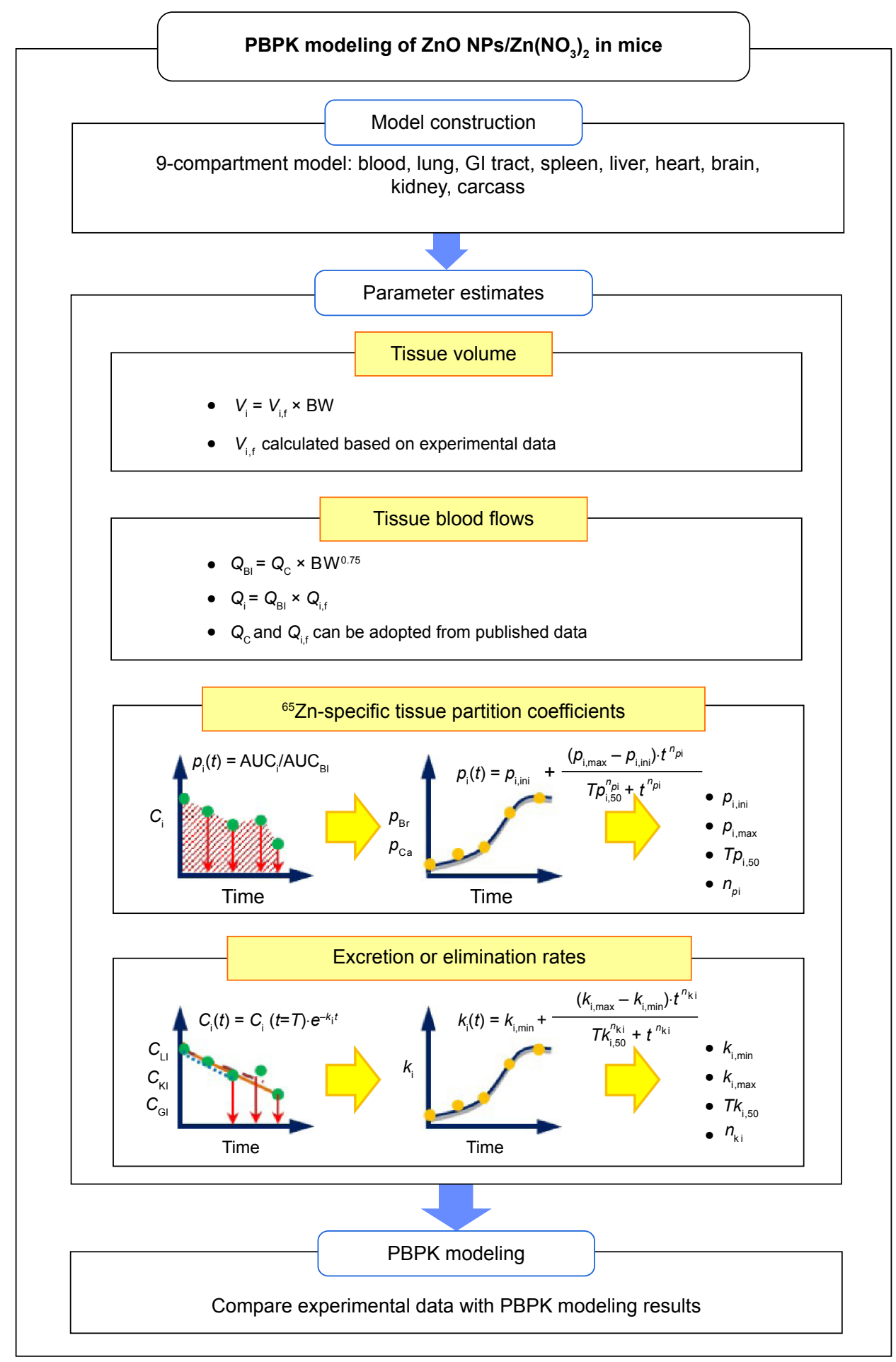

Figure I Schematic of the study framework and computational algorithm.

Abbreviations: $V_{\mathrm{i}}$, tissue volume; $V_{\mathrm{i}, \mathrm{r}}$, percentage tissue volume; BW, body weight; $Q_{\mathrm{B} \mid}$, cardiac output rate; $Q_{\mathrm{C}}$, cardiac output constant; $Q_{\mathrm{i}}$, tissue-specific output rate; $Q_{\mathrm{i}, \mathrm{P}}$ percentage cardiac output rate; $p_{\mathrm{i}}(t)$, partition coefficient at time $t ; A \cup C_{i}$ and $A \cup C_{B l}$, area under the curve of each tissue and blood, respectively; $p_{i, \text { ini }}$, initial value of $p_{i} ; p_{i, m a x}$, maximum value of $p_{i} ; T p_{i, 50}$, time to reach half maximum $p_{i} ; n_{p i}$, Hill coefficient of $p_{i} ; C_{i}(t)$, tissue-specific concentration at time $t$; $C_{i}(t=T)$, tissue-specific concentration estimated by specific time $T ; k_{i}(t)$, excretion or elimination rate at time $t ; k_{i, \text { min }}$, minimum value of $k_{i} ; k_{i, \text { max }}$, maximum value of $k_{i} ; T k_{i, 50}$, time to reach half maximum $k_{i} ; n_{k i}$, Hill coefficient of $k_{;}$; PBPK, physiologically based pharmacokinetics; NP, nanoparticle; $\mathrm{Br}$, brain; $\mathrm{Ca}$, carcass; $\mathrm{GI}$, gastrointestinal; LI, liver; $\mathrm{KI}$, kidney.

system, 3) excretion and elimination rates are described as first-order processes, and 4) complete equilibrium in a chemical exists between blood and tissue phases. Almost all PBPK models can be described by mass balance equations.
Table 1 lists the detailed PBPK model equations and symbols. The model equations were constructed according to the mass transfer of zinc ( $\mathrm{Zn}$ )-containing chemicals and the physiological properties of mice. The liver, GI tract, and 


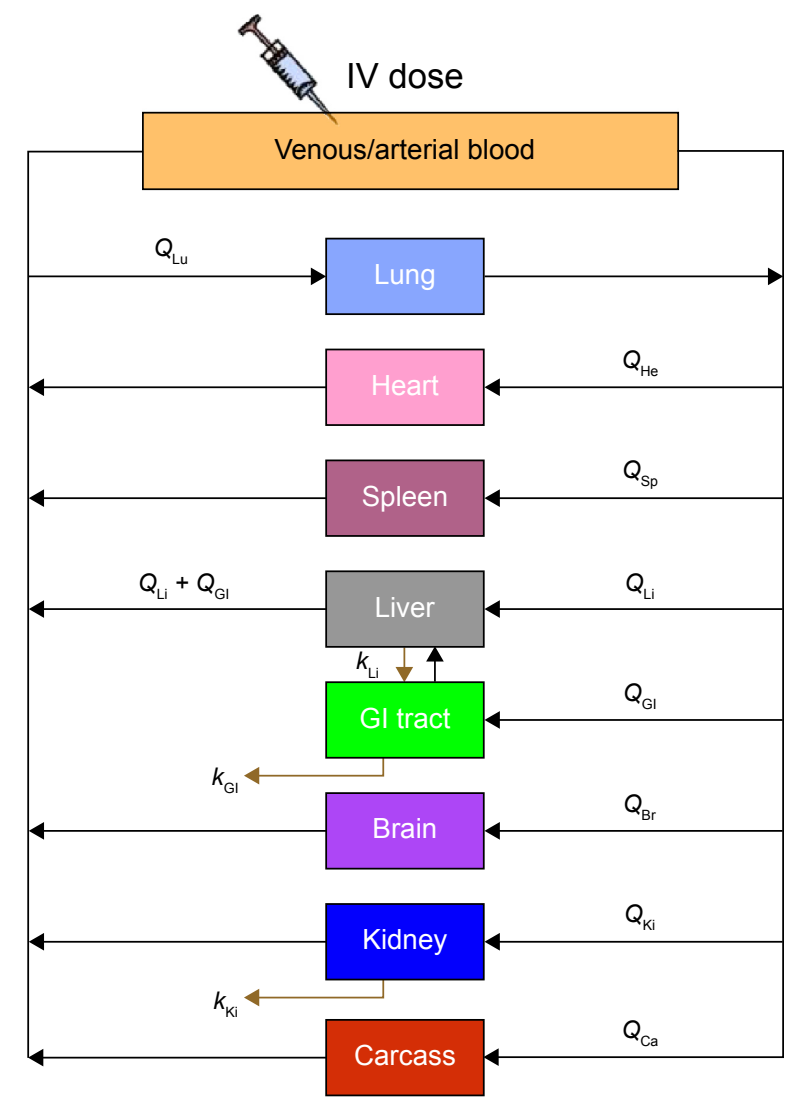

Figure 2 Constructed PBPK model describing the transportation of $10 \mathrm{~nm}$ and $7 \mathrm{~nm}{ }^{65} \mathrm{ZnO} \mathrm{NPs}$ and ${ }^{65} \mathrm{Zn}^{2+}$ and interactions between blood and tissues or organs.

Abbreviations: PBPK, physiologically based pharmacokinetic; NP, nanoparticle; IV, intravenous; GI, gastrointestinal; $Q$, blood flow to organ; $k$, excretion or elimination rate; Li, liver; Ki, kidney; Sp, spleen; Lu, lung; Br, brain; He, heart; Ca, carcass. kidney are the major excreting and eliminating tissues for ${ }^{65} \mathrm{ZnO}$ NPs and ${ }^{65} \mathrm{Zn}\left(\mathrm{NO}_{3}\right)$.

Physiological parameters, including blood and tissue volumes, can be obtained from the experimental data. Exchange rates between tissue and blood compartments can be expressed as a fraction of cardiac output $\left(Q_{\mathrm{Bl}}, \mathrm{L} \cdot \mathrm{h}^{-1}\right)$, in which cardiac output is scaled to body weight using the allometric equation,

$$
Q_{\mathrm{Bl}}=Q_{\mathrm{C}} \mathrm{BW}^{0.75}
$$

where $Q_{\mathrm{C}}$ is the cardiac output constant for a $1 \mathrm{~kg}$ mice and BW is the body weight $(\mathrm{kg}){ }^{13}$ Organ volume constants $\left(V_{\mathrm{i}}\right)$ of mice were scaled to body weight based on a previous study. ${ }^{7}$ Table 2 lists all physiological parameters used in PBPK modeling.

\section{Parameterization and validation}

To acquire the physicochemical parameters of $10 \mathrm{~nm}$ and $71 \mathrm{~nm}{ }^{65} \mathrm{ZnO} \mathrm{NPs}$ and ${ }^{65} \mathrm{Zn}\left(\mathrm{NO}_{3}\right)$, the time-dependent tissue partition coefficients $\left(p_{\mathrm{i}}\right)$ and excretion and elimination rates $\left(k_{\mathrm{i}}\right)$ were considered. The tissue partition coefficient can be estimated by the area under the curve of ${ }^{65} \mathrm{Zn}^{2+}$ or ${ }^{65} \mathrm{ZnO}$ NPs in tissues or blood. Monte Carlo simulation was performed using the calculated mean and standard deviation of the area under the curve of tissues and blood to obtain the distribution of tissue partition coefficients for blood and tissue samples with various

Table I Physiologically based pharmacokinetic model equations in mice

\begin{tabular}{|c|c|c|}
\hline Compartments & Equations & Equation ID \\
\hline Blood $\left(C_{\mathrm{Bl}}, \mu \mathrm{g} \cdot \mathrm{mL}^{-1}\right)$ & 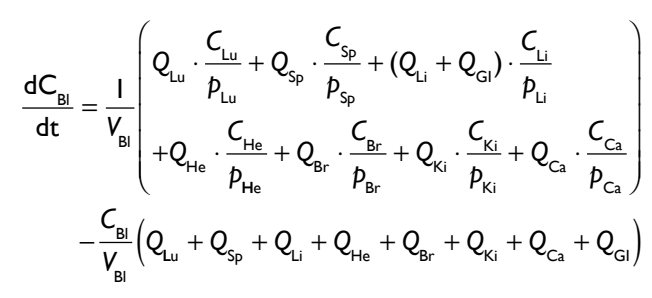 & (A) \\
\hline Lung $\left(C_{\mathrm{Lu}}, \mu g \cdot g^{-1}\right)$ & $\frac{\mathrm{dC}_{\mathrm{Lu}}}{\mathrm{dt}}=\frac{Q_{\mathrm{Lu}}}{V_{\mathrm{Lu}}}\left(C_{\mathrm{Bl}}-\frac{C_{\mathrm{Lu}}}{P_{\mathrm{Lu}}}\right)$ & (B) \\
\hline Gl tract $\left(C_{G l}, \mu g \cdot g^{-1}\right)$ & $\frac{\mathrm{dC}_{\mathrm{Gl}}}{\mathrm{dt}}=\frac{Q_{\mathrm{Gl}}}{V_{\mathrm{GI}}}\left(C_{\mathrm{Bl}}-\frac{C_{\mathrm{Gl}}}{P_{\mathrm{Gl}}}\right)+C_{\mathrm{Li}} \cdot k_{\mathrm{Li}} / P_{\mathrm{Li}}-C_{\mathrm{Gl}} \cdot k_{\mathrm{GI}} / p_{\mathrm{Gl}}$ & (C) \\
\hline Spleen $\left(C_{s p}, \mu g \cdot g^{-1}\right)$ & $\frac{d C_{S_{p}}}{d t}=\frac{Q_{S_{p}}}{V_{S_{p}}}\left(C_{B I}-\frac{C_{S_{p}}}{P_{S_{p}}}\right)$ & (D) \\
\hline Liver $\left(C_{L}, \mu g \cdot g^{-1}\right)$ & $\frac{\mathrm{dC}_{\mathrm{Li}}}{\mathrm{dt}}=\frac{\mathrm{I}}{V_{\mathrm{Li}}}\left(Q_{\mathrm{L} \mid} \cdot C_{\mathrm{B} \mid}+Q_{\mathrm{Gl}} \cdot \frac{C_{\mathrm{Gl}}}{P_{\mathrm{Gl}}}-\left(Q_{\mathrm{LI}}+Q_{\mathrm{G} \mid}\right) \cdot \frac{C_{\mathrm{Li}}}{P_{\mathrm{Li}}}\right)-C_{\mathrm{L}} \cdot k_{\mathrm{Li}} / p_{\mathrm{Li}}$ & $(E)$ \\
\hline
\end{tabular}


Table I (Continued)

\begin{tabular}{|c|c|c|}
\hline Compartments & Equations & Equation ID \\
\hline Heart $\left(C, \mu g \cdot g^{-1}\right)$ & $\frac{\mathrm{dC}_{\mathrm{He}}}{\mathrm{dt}}=\frac{Q_{\mathrm{He}}}{V_{\mathrm{He}}}\left(C_{\mathrm{Bl}}-\frac{C_{\mathrm{He}}}{P_{\mathrm{He}}}\right)$ & (F) \\
\hline $\operatorname{Brain}\left(C_{\mathrm{Br}}, \mu g \cdot g^{-1}\right)$ & $\frac{\mathrm{dC}_{\mathrm{Br}}}{\mathrm{dt}}=\frac{Q_{\mathrm{Br}}}{V_{\mathrm{Br}}}\left(C_{\mathrm{Bl}}-\frac{C_{\mathrm{Br}}}{P_{\mathrm{Br}}}\right)$ & (G) \\
\hline Kidney $\left(C_{\mathrm{Ki}}, \mu g \cdot g^{-1}\right)$ & $\frac{\mathrm{d} C_{\mathrm{Ki}}}{\mathrm{dt}}=\frac{Q_{\mathrm{Ki}}}{V_{\mathrm{Ki}}}\left(C_{\mathrm{Bl}}-\frac{C_{\mathrm{Ki}}}{P_{\mathrm{Ki}}}\right)-C_{\mathrm{Ki}} \cdot k_{\mathrm{Ki}} / P_{\mathrm{Ki}}$ & $(\mathrm{H})$ \\
\hline $\operatorname{Carcass}\left(C_{\mathrm{Ca}^{\prime}}, \mu g \cdot g^{-1}\right)$ & $\frac{\mathrm{dC}_{\mathrm{Ca}_{\mathrm{a}}}}{\mathrm{dt}}=\frac{Q_{\mathrm{Ca}_{\mathrm{a}}}}{V_{\mathrm{Ca}_{\mathrm{a}}}}\left(C_{\mathrm{Bl}}-\frac{C_{\mathrm{Ca}_{\mathrm{a}}}}{P_{\mathrm{Ca}}}\right)$ & (l) \\
\hline
\end{tabular}

Abbreviations: $C$, concentration; $V$, tissue volume; $Q$, Blood flow to organ; $p$, partition coefficient; $k$, excretion or elimination rate; $\mathrm{Bl}$, blood; Li, liver; Ki, kidney; Sp, spleen; Lu, lung; Br, brain; He, heart; GI, gastrointestinal; Ca, carcass.

plausible combinations. The distributions were assumed to be lognormal to avoid negative values caused by high deviations. The individual variability of mice was also incorporated into the tissue partition coefficient estimates. The time-dependent partition coefficients for carcass and brain were sigmoidal, whereas a peak curve was observed for other tissues. Crystal Ball ${ }^{\circledR}$ software (Version 2000.2; Decisioneering Inc, Denver, CO, USA) was used for Monte Carlo simulation to obtain the 2.5 and 97.5 percentiles as $95 \%$ confidence intervals.

Table 2 Physiological parameters used in PBPK model for ${ }^{65} \mathrm{ZnO}$ $\mathrm{NPs}$ and ${ }^{65} \mathrm{Zn}\left(\mathrm{NO}_{3}\right)_{2}$ in mice

\begin{tabular}{|c|c|c|c|}
\hline Symbol & Value & Description (unit) & Source \\
\hline BW & 0.032 & Body weight $(\mathrm{kg})$ & Estimated \\
\hline$Q_{\mathrm{C}}$ & 9.025 & $\begin{array}{l}\text { Cardiac output constant } \\
\left(\mathrm{L} \cdot \mathrm{h}^{-1}\right)\end{array}$ & Davies and Morris ${ }^{13}$ \\
\hline \multicolumn{4}{|c|}{ Organ volume (as percentage of BW) } \\
\hline$V_{\mathrm{BI}}$ & 0.060 & Blood volume & Estimated \\
\hline$V_{\text {Lu }}^{B l}$ & 0.007 & Lung volume & Estimated \\
\hline$V_{G}^{\text {Lu }}$ & 0.127 & Gl tract volume & Estimated \\
\hline$V_{S p}^{G}$ & 0.004 & Spleen volume & Estimated \\
\hline$V_{\mathrm{Li}}^{\mathrm{SP}}$ & 0.059 & Liver volume & Estimated \\
\hline$V_{\mathrm{He}}^{\mathrm{LI}}$ & 0.007 & Heart volume & Estimated \\
\hline$V_{\mathrm{Br}}^{\mathrm{He}}$ & 0.014 & Brain volume & Estimated \\
\hline$V_{\mathrm{Ki}}^{\mathrm{Di}}$ & 0.016 & Kidney volume & Estimated \\
\hline$V_{\mathrm{Ca}_{\mathrm{a}}}^{\mathrm{kI}}$ & 0.706 & Carcass volume & Estimated \\
\hline \multicolumn{4}{|c|}{ Blood flow to organ (as percentage of cardiac output) } \\
\hline$Q_{\text {Lu }}$ & 1 & Lung blood flow & Brown et al $^{18}$ \\
\hline$Q_{\mathrm{Gl}}^{\mathrm{Lu}}$ & 0.188 & Gl tract blood flow & Davies and Morris ${ }^{13}$ \\
\hline$Q_{\mathrm{Sp}}$ & 0.011 & Spleen blood flow & Davies and Morris ${ }^{13}$ \\
\hline$Q_{\mathrm{Li}}^{\mathrm{SP}}$ & 0.161 & Liver blood flow & Davies and Morris ${ }^{13}$ \\
\hline$Q_{\mathrm{He}}$ & 0.060 & Heart blood flow & Brown et $\mathrm{al}^{18}$ \\
\hline$Q_{\mathrm{Br}}$ & 0.030 & Brain blood flow & Brown et al ${ }^{18}$ \\
\hline$Q_{\mathrm{Ki}}$ & 0.091 & Kidney blood flow & Brown et al ${ }^{18}$ \\
\hline$Q_{\mathrm{Ca}}$ & 0.454 & Carcass blood flow & Estimated \\
\hline
\end{tabular}

Abbreviations: PBPK, physiologically based pharmacokinetic; NP, nanoparticle; $\mathrm{BW}$, body weight; $\mathrm{GI}$, gastrointestinal; $Q_{c}$, cardiac output constant; $V$, tissue volume; $Q$, Blood flow to organ; Bl, blood; Li, liver; Ki, kidney; Sp, spleen; Lu, lung; Br, brain; $\mathrm{He}$, heart; $\mathrm{Ca}$, carcass.
A four-parameter Hill function can be used to describe the time-dependent partition coefficient of heart, brain, and carcass in ${ }^{65} \mathrm{Zn}\left(\mathrm{NO}_{3}\right)_{2}$ and that of brain and carcass in $10 \mathrm{~nm}$ and $70 \mathrm{~nm}{ }^{65} \mathrm{ZnO}$ NPs in a sigmoid manner,

$$
p_{\mathrm{i}}(t)=p_{\mathrm{i}, \text { ini }}+\frac{\left(p_{\mathrm{i}, \max }-p_{\mathrm{i}, \text { ini }}\right) \cdot t^{n_{p_{\mathrm{i}}}}}{T p_{\mathrm{i}, 50}^{n_{p_{\mathrm{i}}}}+t^{n_{p_{\mathrm{i}}}}}
$$

where $p_{\mathrm{i}}(t)$ is the time-dependent partition coefficient $(-), p_{\mathrm{i}, \text { ini }}$ is the initial partition coefficient $(-), p_{\mathrm{i}, \max }$ is the maximum partition coefficient (-), $T p_{\mathrm{i}, 50}$ is the time constant at $50 \%$ maximum partition coefficient (hours), $t$ is the time (hours), and $n_{p \mathrm{i}}$ is the Hill coefficient (-).

Typically, excretion or elimination rate constant estimates can be determined by a depuration process in a contaminated organism without ${ }^{65} \mathrm{ZnO} \mathrm{NP}$ or ${ }^{65} \mathrm{Zn}\left(\mathrm{NO}_{3}\right)_{2}$ injection. Therefore, the kinetics of the depuration process,

$$
C_{\mathrm{i}}(t)=C_{\mathrm{i}}(t=T) e^{-k_{\mathrm{i}} t}
$$

where $C_{\mathrm{i}}(t)$ is the time-dependent ${ }^{65} \mathrm{ZnO} \mathrm{NP}$ or ${ }^{65} \mathrm{Zn}\left(\mathrm{NO}_{3}\right)_{2}$ concentration in tissue $i\left(\mu \mathrm{g} \cdot \mathrm{g}^{-1}\right), C_{\mathrm{i}}(t=T)$ is the concentration at time $T$ (hours) when depuration begins, and $k_{\mathrm{i}}$ is the excretion or elimination rate constant $\left(\mathrm{h}^{-1}\right)$, can be used to estimate excretion or elimination rate constants. The results at the end of the experimental period showed that the accumulated $\mathrm{Zn}$ was substantially less than the initial administered dose. Thus, time-dependent maximum and half-maximum excretion or elimination rates can also markedly affect ${ }^{65} \mathrm{ZnO}$ $\mathrm{NP}$ or ${ }^{65} \mathrm{Zn}\left(\mathrm{NO}_{3}\right)_{2}$ accumulation.

Time-dependent excretion and elimination were considered to occur in ${ }^{65} \mathrm{ZnO} \mathrm{NP}$ or ${ }^{65} \mathrm{Zn}\left(\mathrm{NO}_{3}\right)_{2}$ kinetic processes, 


$$
k_{\mathrm{i}}(t)=k_{\mathrm{i}, \min }+\frac{\left(k_{\mathrm{i}, \max }-k_{\mathrm{i}, \min }\right)}{\left(1+\left(\frac{t}{T k_{\mathrm{i}, 50}}\right)^{\mathrm{n}_{\mathrm{k}_{\mathrm{i}}}}\right)}
$$

where $k_{\mathrm{i}, \min }$ is the minimum excretion or elimination rate constant $\left(\mathrm{h}^{-1}\right), k_{\mathrm{i}, \max }$ is the maximum excretion or elimination rate constant $\left(\mathrm{h}^{-1}\right), T k_{\mathrm{i}, 50}$ is the time constant at $50 \%$ maximum excretion or elimination rate (hours), and $n_{\mathrm{k}_{\mathrm{j}}}$ is the Hill coefficient (-). TableCurve 2D (Version 5; AISN Software Inc, Mapleton, OR, USA) was used to fit the experimental data to obtain the optimally fitted statistical model. The generated coefficients of determination $\left(r^{2}\right)$ can be used to examine the goodness of fit of selected nonlinear statistical models.

To investigate differences in size- and tissue-specific accumulation trends, mean residence times of ${ }^{65} \mathrm{ZnO}$ NPs and ${ }^{65} \mathrm{Zn}\left(\mathrm{NO}_{3}\right)_{2}$ in tissues were calculated. Mathematically, mean residence time can be defined as:

$$
\bar{t}_{\mathrm{i}}=\frac{\int_{0}^{\mathrm{t}} t C_{\mathrm{i}}(t) \mathrm{dt}}{\int_{0}^{\mathrm{t}} C_{\mathrm{i}}(t) \mathrm{dt}}
$$

where $\bar{t}_{\mathrm{i}}$ is the mean residence time (hours) and $C_{\mathrm{i}}(t)$ is the tissue concentration profile $\left(\mu \mathrm{g} \cdot \mathrm{g}^{-1}\right){ }^{14}$

The Berkeley Madonna: Modeling and Analysis of Dynamic Systems (Version 8.3.9; University of California, Berkley, CA, USA) was used to perform all PBPK simulations for ${ }^{65} \mathrm{ZnO}$ NPs and ${ }^{65} \mathrm{Zn}\left(\mathrm{NO}_{3}\right)_{2}$ in mice. To assess the performance of model predictability, the mean absolute percentage error (MAPE) was calculated as: ${ }^{: 5,16}$

$$
\mathrm{MAPE}=\frac{1}{N} \sum_{\mathrm{n}=1}^{\mathrm{N}} \frac{\left|C_{\mathrm{o}, \mathrm{n}}-C_{\mathrm{m}, \mathrm{n}}\right|}{C_{\mathrm{o}, \mathrm{n}}} \times 100 \%
$$

where $N$ denotes the number of observations, $C_{\mathrm{o}, \mathrm{n}}$ is the observed biodistribution data from blood and each tissue of ${ }^{65} \mathrm{ZnO}$ NPs and ${ }^{65} \mathrm{Zn}\left(\mathrm{NO}_{3}\right)_{2}$, and $C_{\mathrm{m}, \mathrm{n}}$ is the modeled result corresponding to blood- and tissue-specific data point $n$. Further calibration might be required to obtain the optimal fit of pharmacokinetics to experimental data. To perform further calibration of the experimental data, the estimated tissue-specific excretion or elimination rates and partition coefficients would be adjusted based on our study hypothesis and the characteristics of ${ }^{65} \mathrm{ZnO} N P s$ and ${ }^{65} \mathrm{Zn}\left(\mathrm{NO}_{3}\right)_{2}$ to reduce the MAPE values.

\section{Sensitivity analysis}

A sensitivity analysis was performed to identify the influence of critical variables in the algorithm on tissue accumulation.
To test sensitivity, the partition coefficients and excretion and elimination rates were increased by $10 \%$ to iterate the model simulation and to identify significant changes in the modeled accumulation distribution. The sensitivity ratios were calculated as:

$$
\mathrm{SR}=\frac{\Delta C / C_{\mathrm{o}}}{\Delta x / x_{\mathrm{o}}}
$$

where $\Delta C$ is the difference between the resulting and original $\left(Y_{\mathrm{o}}\right)$ predicted concentration values, and $\Delta x$ is the difference between the resulting and initial $\left(x_{0}\right)$ parameter values.

\section{Results}

\section{Particle size-dependent physicochemical parameters}

Our results indicated that the calculated tissue partition coefficients of $10 \mathrm{~nm}{ }^{65} \mathrm{ZnO}$ NPs were greater than those of $71 \mathrm{~nm}$ ${ }^{65} \mathrm{ZnO} N P s$ and ${ }^{65} \mathrm{Zn}\left(\mathrm{NO}_{3}\right)_{2}$, except for the partition coefficients of $71 \mathrm{~nm}{ }^{65} \mathrm{ZnO}$ NPs in the liver and kidney at 672 hours, GI tract at 24-672 hours, and carcass at 1 hour and 24-672 hours. Tables S1-S3 list the detailed time-dependent partition coefficients of $10 \mathrm{~nm}$ and $71 \mathrm{~nm}{ }^{65} \mathrm{ZnO} N P s$ and ${ }^{65} \mathrm{Zn}\left(\mathrm{NO}_{3}\right)_{2}$. The increases in the partition coefficients of brain and carcass were time-dependent. The four-parameter Hill function in Equation 2 was optimally fitted to the partition coefficient of brain and carcass over time $\left(r^{2}=0.97-0.99\right)$, and Hill coefficients were significant $(>1)$ for both. Table 3 shows the estimates of the Hill parameters for brain and carcass partition coefficients.

Table S4 lists the estimated excretion or elimination rate constants of ${ }^{65} \mathrm{ZnO} \mathrm{NPs}$ and ${ }^{65} \mathrm{Zn}\left(\mathrm{NO}_{3}\right)_{2}$. The estimated time-dependent excretion or elimination rates for $10 \mathrm{~nm}$ and $71 \mathrm{~nm}{ }^{65} \mathrm{ZnO}$ NPs and ${ }^{65} \mathrm{Zn}\left(\mathrm{NO}_{3}\right)_{2}$ marginally decreased during the 28-day experimental period. Furthermore, a significant decreasing trend of excretion or elimination rate following the order ${ }^{65} \mathrm{Zn}\left(\mathrm{NO}_{3}\right)_{2}, 71 \mathrm{~nm}{ }^{65} \mathrm{ZnO} \mathrm{NPs}$, and $10 \mathrm{~nm}$ ${ }^{65} \mathrm{ZnO}$ NPs were observed in kidneys and GI tract and not in the liver (Table S4).

\section{Simulation and model validation}

Figures 3 and 4 show comparisons between the results from PBPK model simulation (solid line, without calibration; dashed line, with calibration, after 7 days of exposure) and the experimental data on tissue and blood concentrations of $10 \mathrm{~nm}$ and $71 \mathrm{~nm}{ }^{65} \mathrm{ZnO}$ NPs and ${ }^{65} \mathrm{Zn}\left(\mathrm{NO}_{3}\right)_{2}$. To perform PBPK simulation, we considered the timedependent excretion or elimination rates and partition coefficients of $10 \mathrm{~nm}$ and $71 \mathrm{~nm}{ }^{65} \mathrm{ZnO}$ NPs and ${ }^{65} \mathrm{Zn}\left(\mathrm{NO}_{3}\right)_{2}$. 
Table 3 Physicochemical parameters used in PBPK model for ${ }^{65} \mathrm{ZnO}$ NPs and ${ }^{65} \mathrm{Zn}\left(\mathrm{NO}_{3}\right)_{2}$ in mice

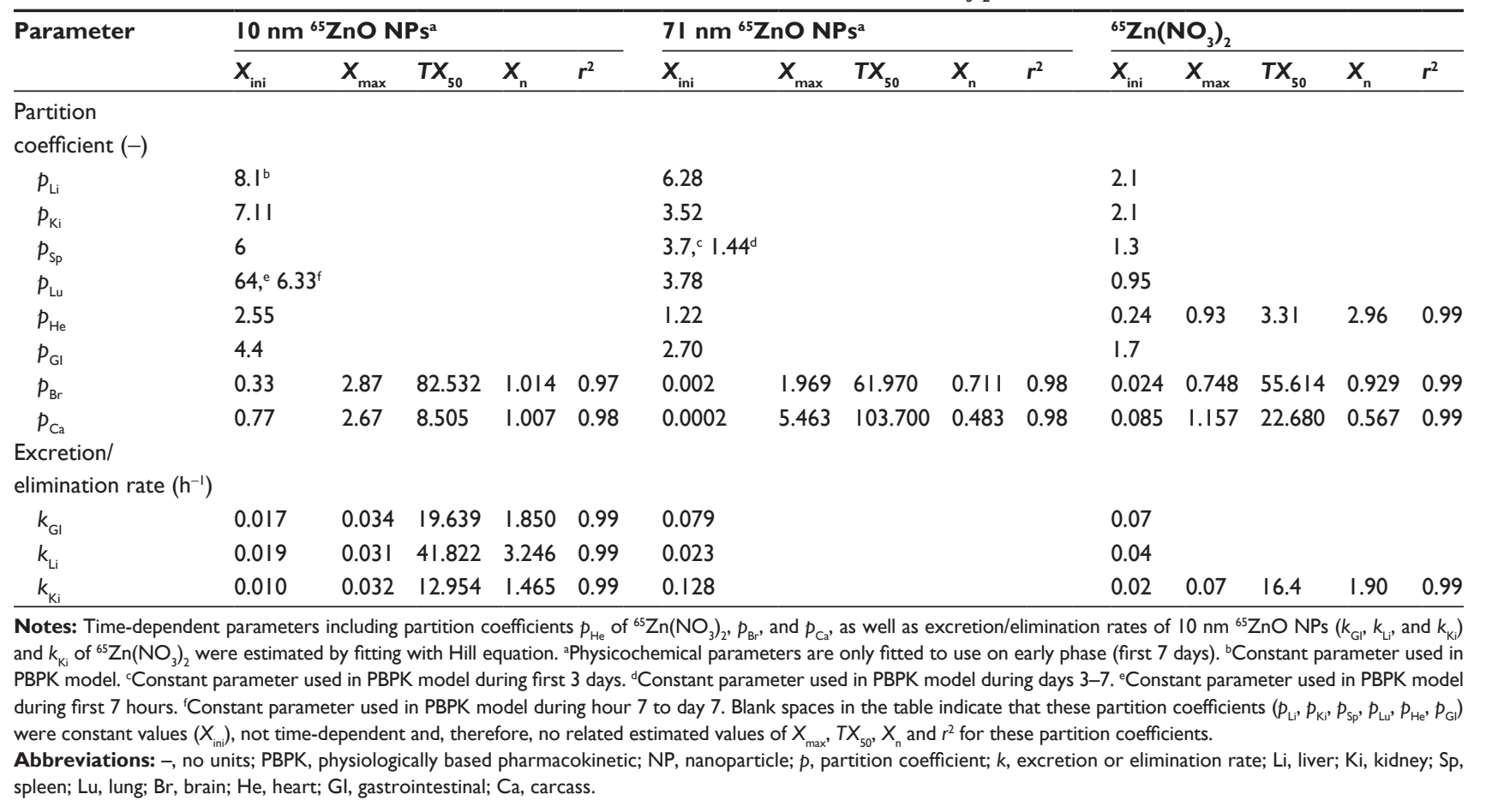

Specifically, the concentration of $10 \mathrm{~nm}{ }^{65} \mathrm{ZnO}$ NPs in the lung showed a higher accumulative capacity than those of $71 \mathrm{~nm}{ }^{65} \mathrm{ZnO}$ NPs and ${ }^{65} \mathrm{Zn}\left(\mathrm{NO}_{3}\right)_{2}$ for the first 7 hours (Figure 3). Moreover, the concentration of $71 \mathrm{~nm}{ }^{65} \mathrm{ZnO}$ NPs decreased substantially to almost zero from days 3 to 7 in the spleen. Therefore, we used optimized partition coefficients (listed in Table 3 ) to simulate and describe ${ }^{65} \mathrm{ZnO}$ NPs concentration profiles over time in the lung and spleen (Figure 3A-F).

The majority of the experimental concentration profiles of ${ }^{65} \mathrm{ZnO}$ NPs and ${ }^{65} \mathrm{Zn}\left(\mathrm{NO}_{3}\right)_{2}$ in the target tissues of mice rapidly increased within a few hours of intravenous injection and decreased thereafter (Figures 3A-R and 4), whereas concentrations profiles in the brain and carcass increased and then slightly decreased during the 7-day period (Figure 3S-X). The time-dependent increasing functions of the partition coefficients might thus be suitable to describe the biodistributions of ${ }^{65} \mathrm{ZnO}$ NPs and ${ }^{65} \mathrm{Zn}\left(\mathrm{NO}_{3}\right)_{2}$ in mice brain and carcass (Table 3 ).

During the late phase (days 7-28), we observed that tissue concentration markedly decreased and that our simulation of ${ }^{65} \mathrm{ZnO}$ NPs barely fit the experimental data. Yet, the simulation of ${ }^{65} \mathrm{Zn}(\mathrm{NO})_{3}$ was well fitted with the experimental data. Therefore, it is likely that ${ }^{65} \mathrm{ZnO}$ NPs gradually decompose into zinc ion after 7 days. Indeed, similar results were also observed in a previous study. ${ }^{17}$ We proposed that the ${ }^{65} \mathrm{ZnO}$ NPs might decompose after day 7 , resulting in a markedly decreasing trend on day 28. For that, we replaced the partition coefficients and excretion or elimination rates of $10 \mathrm{~nm}$ and $71 \mathrm{~nm}{ }^{65} \mathrm{ZnO}$ NPs after day 7 with those estimated from ${ }^{65} \mathrm{Zn}\left(\mathrm{NO}_{3}\right)_{2}$ experimental data. All partition coefficients used for calibration are listed in Table 4.

Overall, our results indicated that the PBPK simulations with calibration reasonably agreed with the experimentally determined values of the time-dependent ${ }^{65} \mathrm{ZnO} \mathrm{NP}$ and ${ }^{65} \mathrm{Zn}\left(\mathrm{NO}_{3}\right)_{2}$ concentrations (MAPE <50\%) (Figure 5). Notably, $10 \mathrm{~nm}{ }^{65} \mathrm{ZnO}$ NPs of the heart and brain and $71 \mathrm{~nm}$ ${ }^{65} \mathrm{ZnO}$ NPs of the liver and carcass provided good predictions $(10 \% \leq$ MAPE $<20 \%)$. The PBPK simulation outcome for ${ }^{65} \mathrm{Zn}\left(\mathrm{NO}_{3}\right)_{2}$ concentration in the kidney provided an excellent prediction (MAPE $<10 \%$ ).

\section{Mean residence time estimation and sensitivity analysis}

We used the experimental accumulation data obtained using Equation 5 to estimate the mean residence times of ${ }^{65} \mathrm{ZnO}$ NPs and ${ }^{65} \mathrm{Zn}\left(\mathrm{NO}_{3}\right)_{2}$ in each tissue. As shown in Figure 6A, the mean residence times of the majority of tissues ranged from 7 days to 14 days. Generally, the mean residence time of $10 \mathrm{~nm}{ }^{65} \mathrm{ZnO}$ NPs was longer than those of ${ }^{65} \mathrm{Zn}\left(\mathrm{NO}_{3}\right)_{2}$ and $71 \mathrm{~nm}{ }^{65} \mathrm{ZnO}$ NPs (Figure 6B). These results indicated that $10 \mathrm{~nm}{ }^{65} \mathrm{ZnO}$ NPs in the blood, brain, heart, and carcass and $71 \mathrm{~nm}{ }^{65} \mathrm{ZnO}$ NPs and ${ }^{65} \mathrm{Zn}\left(\mathrm{NO}_{3}\right)_{2}$ in the brain and carcass had mean residence times close to the highest outliers 

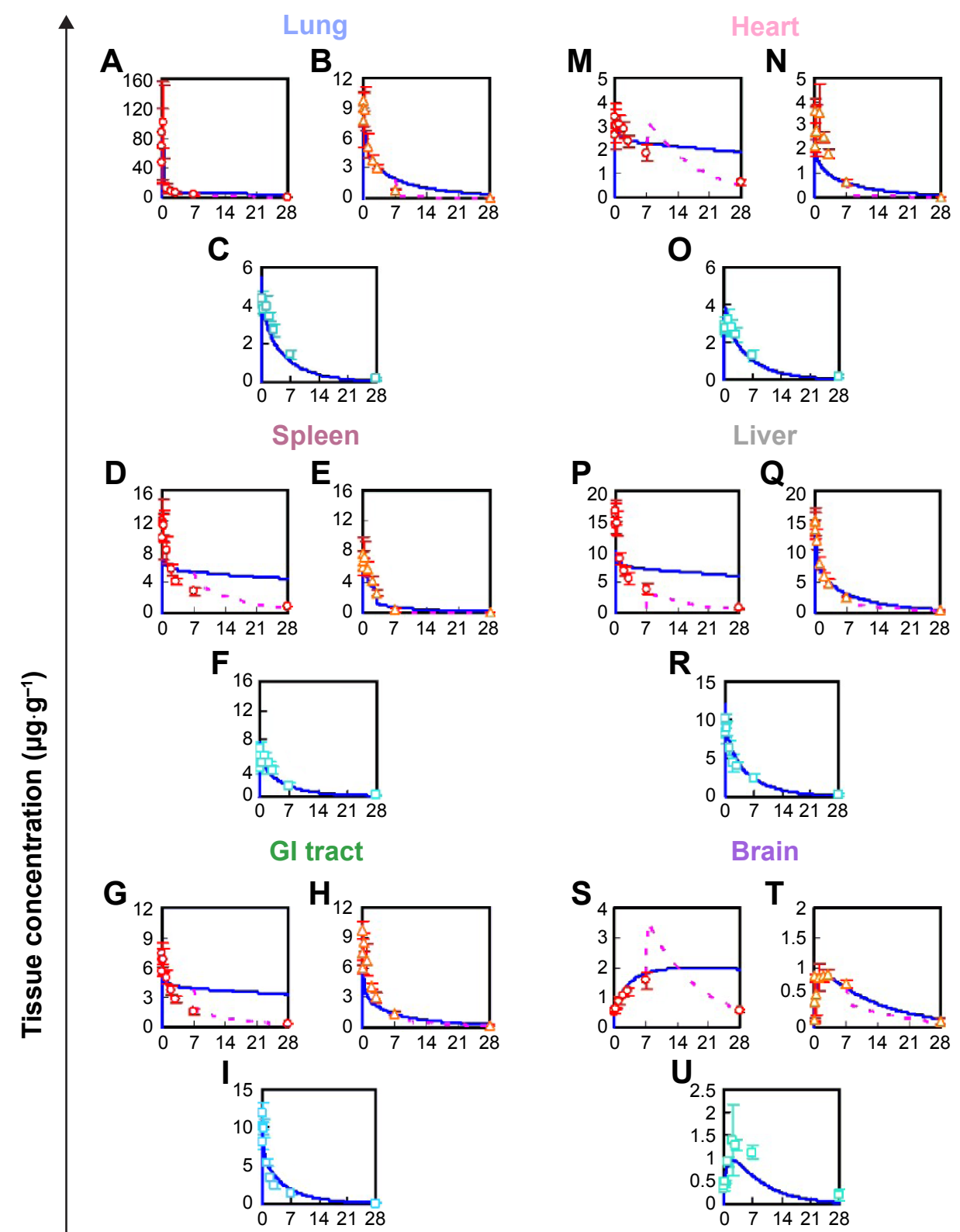

Brain
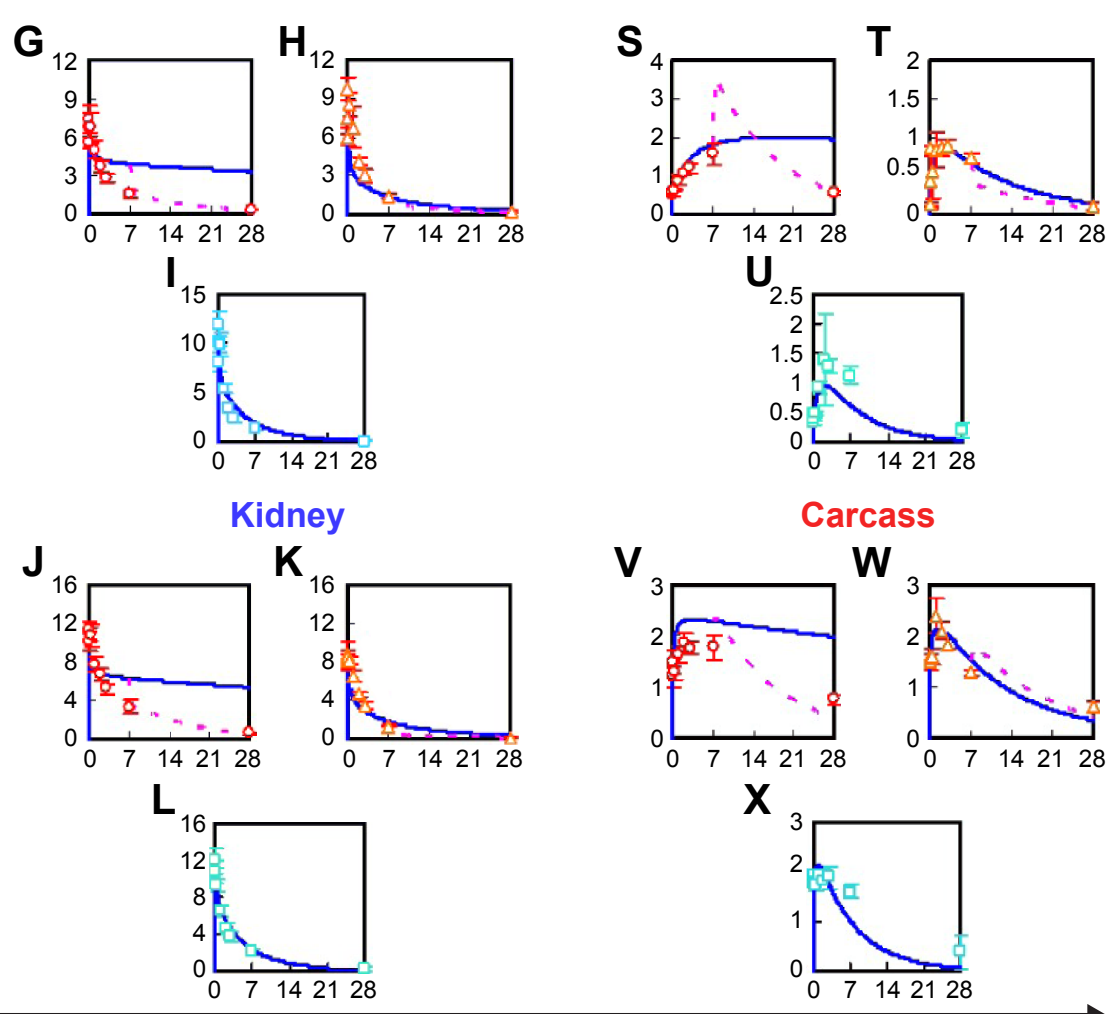

Time (days)

Figure 3 Comparisons between PBPK model simulations and pharmacokinetics in mice lung (A-C), spleen (D-F), GI tract (G-I), kidney (J-L), heart (M-O), liver (P-R), brain $(\mathbf{S}-\mathbf{U})$, and carcass $(\mathbf{V}-\mathbf{X})$ after intravenous injection of $10 \mathrm{~nm}$ (circle) and $7 \mathrm{I} \mathrm{nm} \mathrm{(triangle)}{ }^{65} \mathrm{ZnO} \mathrm{NPs}_{\text {and }}{ }^{65} \mathrm{Zn}\left(\mathrm{NO}_{3}\right)_{2}(\mathrm{square})$.

Note: Solid and dashed lines represent simulations without and with calibration, respectively, before and after 7-day exposure.

Abbreviations: PBPK, physiologically based pharmacokinetic; NP, nanoparticle; GI, gastrointestinal. 


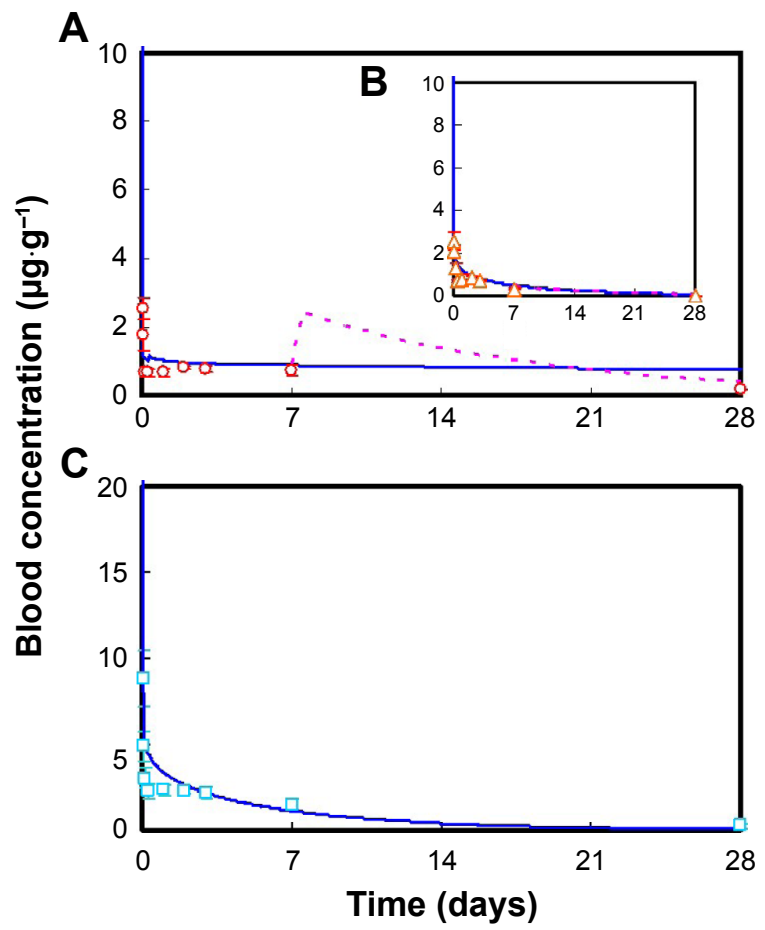

Figure 4 Comparisons between PBPK model simulations and pharmacokinetics of mice in blood after intravenous injection of (A) $10 \mathrm{~nm}$ and (B) $71 \mathrm{~nm}{ }^{65} \mathrm{ZnO} N P s$, and $(\mathbf{C}){ }^{65} \mathrm{Zn}\left(\mathrm{NO}_{3}\right)_{2}$.

Notes: Solid and dashed lines represent simulations without and with calibration, respectively. Circles, triangles, and squares represent blood concentration data of $10 \mathrm{~nm}$, and $71 \mathrm{~nm}{ }^{65} \mathrm{ZnO} \mathrm{NP}$, and ${ }^{65} \mathrm{Zn}\left(\mathrm{NO}_{3}\right)$, respectively.

Abbreviations: PBPK, physiologically based pharmacokinetic; NP, nanoparticle.

of 14 days, whereas $71 \mathrm{~nm}{ }^{65} \mathrm{ZnO}$ NPs in the spleen had the lowest mean residence time of 4.55 days ( $95 \%$ confidence interval: 1.14-2.07).

Figure 7 shows the critical variables in our sensitivity analyses for tissue concentrations during the 7-day period. The sensitivity analyses indicated that ${ }^{65} \mathrm{Zn}\left(\mathrm{NO}_{3}\right)_{2}$ tissue concentrations were most sensitive to the increased

Table 4 Physicochemical parameters used in PBPK model for ${ }^{65} \mathrm{ZnO}$ NPs in mice after day 7

\begin{tabular}{cll}
\hline Parameter & $\mathbf{1 0} \mathbf{~ n m}{ }^{65} \mathbf{Z n O} \mathbf{~ N P s}$ & $\mathbf{7 1 ~} \mathbf{~ m}{ }^{65} \mathbf{Z n O} \mathbf{~ N P s}$ \\
\hline Partition coefficient $(-)$ & \\
$P_{\mathrm{Li}}$ & 1.32 & 3.53 \\
$P_{\mathrm{Ki}}$ & 1.42 & 0.91 \\
$P_{\mathrm{SP}}$ & 1.54 & 0.26 \\
$P_{\mathrm{Lu}}$ & 1.25 & 0.34 \\
$P_{\mathrm{He}}$ & 1.25 & 0.20 \\
$P_{\mathrm{Gl}}$ & 0.63 & 1.63 \\
$P_{\mathrm{Br}}$ & 1.42 & 0.93 \\
$P_{\mathrm{Ca}}$ & 0.96 & 4.45 \\
Excretion/elimination & rate $\left(\mathrm{h}^{-1}\right)$ & \\
$k_{\mathrm{Gl}}$ & 0.0343 & 0.0788 \\
$k_{\mathrm{Li}}$ & 0.0192 & 0.0229 \\
$k_{\mathrm{Ki}}$ & 0.0319 & 0.1277 \\
\hline
\end{tabular}

Abbreviations: PBPK, physiologically based pharmacokinetic; NP, nanoparticle; Li, liver; Ki, kidney; Sp, spleen; Lu, lung; Br, brain; He, heart; Gl, gastrointestinal; $\mathrm{Ca}$, carcass.

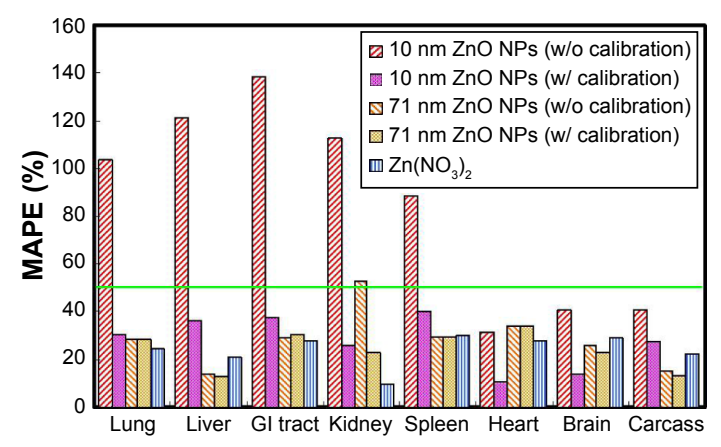

Figure 5 MAPE estimates showing the performances of model predictability of $10 \mathrm{~nm}$ and $71 \mathrm{~nm}{ }^{65} \mathrm{ZnO} \mathrm{NPs}$ and ${ }^{65} \mathrm{Zn}\left(\mathrm{NO}_{3}\right)_{2}$, with and without calibration. Note: The horizontal line indicates reasonable prediction with MAPE $<50 \%$. Abbreviations: MAPE, mean absolute percentage error; NP, nanoparticle; w/, with; w/o, without; GI, gastrointestinal.

excretion or elimination rate of the liver $\left(k_{\mathrm{Li}}\right.$, sensitive coefficient: 0.46 ) and that the partition coefficient of the lung $\left(p_{\mathrm{Lu}}\right)$ presented the most sensitive coefficient of 0.54 in $10 \mathrm{~nm}^{65} \mathrm{ZnO}$ NPs. However, parameters that increased in correspondence with a decrease in tissue concentration included the excretion or elimination rates of the GI tract and kidney for all chemicals, the partition coefficients of the GI tract $(-0.06)$ and carcass $(-0.32)$ for $10 \mathrm{~nm}{ }^{65} \mathrm{ZnO}$ NPs, and the partition coefficients of the carcass $(-0.14)$ for $71 \mathrm{~nm}{ }^{65} \mathrm{ZnO}$ NPs.

\section{Discussion}

$\mathrm{ZnO} \mathrm{NP}$ has been proposed to gradually decompose into zinc ion in the biological system. However, our data showed that the tissue kinetics of ${ }^{65} \mathrm{ZnO}$ NP were still different from those of zinc ion in mice. By comparing the PBPK parameters of ${ }^{65} \mathrm{ZnO} \mathrm{NP}$ and ${ }^{65} \mathrm{Zn}^{2+}$, we are able to propose that majority of ${ }^{65} \mathrm{ZnO} \mathrm{NP}$ in tissues might decompose after day 7. And incorporating the parameters of zinc ion into ${ }^{65} \mathrm{ZnO} \mathrm{NP}$ model after day 7 would improve the simulation. Our study shows that it is possible to construct a PBPK model for slowly decomposed NPs, by comparing the kinetics of NPs and soluble elements.

\section{Critical parameters and associated effects of PBPK model}

Our ${ }^{65} \mathrm{ZnO}$ NP PBPK model for ${ }^{65} \mathrm{ZnO}$ NPs fitted well with the accumulation of various size ${ }^{65} \mathrm{ZnO}$ NPs in mice tissues. In a PBPK model, the partition coefficient is the key parameter affecting accumulation levels in tissues. ${ }^{18}$ Although it is often assumed that partitioning between tissues and blood reaches equilibrium after 24 hours, increasing evidence suggests that equilibrium for NPs in specific tissues is reached after several days to several months and that the concentrations in these 


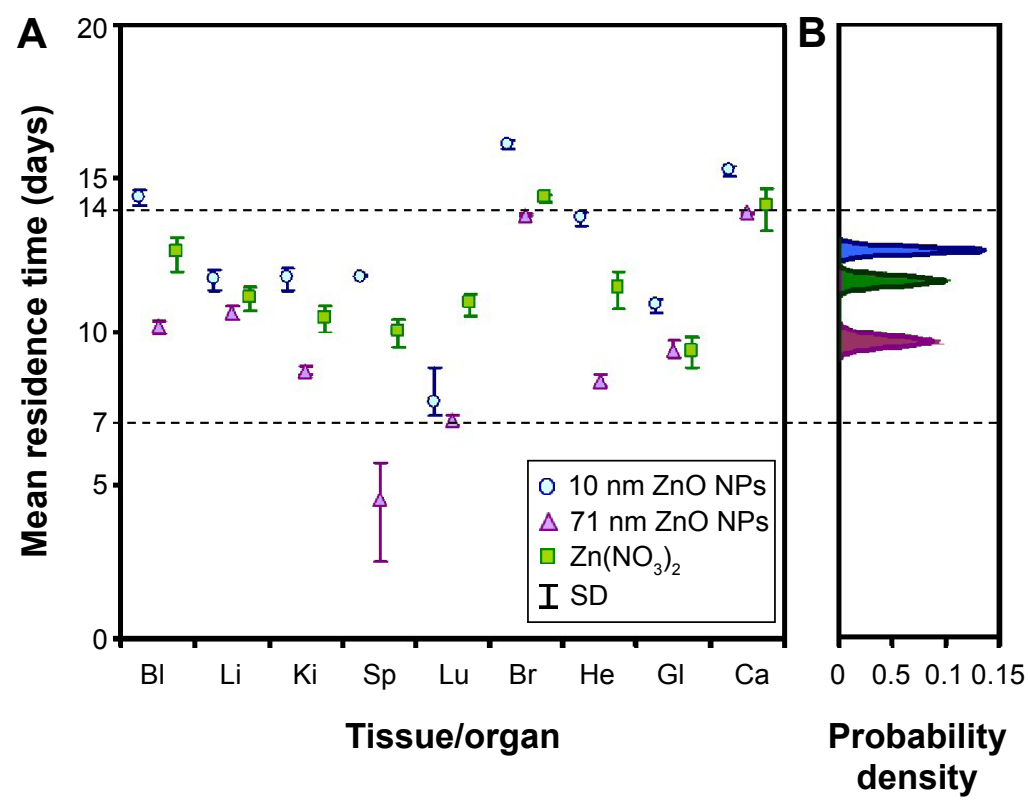

Figure 6 Tissue-specific mean residence times and probability density of $10 \mathrm{~nm}$ and $7 \mathrm{I} \mathrm{nm}{ }^{65} \mathrm{ZnO}$ NPs and ${ }^{65} \mathrm{Zn}\left(\mathrm{NO}_{3}\right)_{2}$ accumulations.

Notes: (A) Tissue-specific mean residence times of $10 \mathrm{~nm}$ and $7 \mathrm{Imm}{ }^{65} \mathrm{ZnO}$ NPs and ${ }^{65} \mathrm{Zn}\left(\mathrm{NO}_{3}\right)_{2}$ (range: $7-14$ days) and (B) probability density distributions of mean residence times of $10 \mathrm{~nm}$ (blue) and $7 \mathrm{I} \mathrm{nm}$ (purple) ${ }^{65} \mathrm{ZnO} \mathrm{NPs}$ and ${ }^{65} \mathrm{Zn}\left(\mathrm{NO}_{3}\right)_{2}$ (green).

Abbreviations: NP, nanoparticle; SD, standard deviation; BI, blood; Li, liver; Ki, kidney; Sp, spleen; Lu, lung; Br, brain; He, heart; Gl, gastrointestinal; Ca, carcass.

organs can increase several fold with increasing duration of exposure. ${ }^{19-23}$ Thus, the constant partition coefficients estimated from the steady-state condition might not be able to assess the biodistributions of ${ }^{65} \mathrm{ZnO}$ NPs and ${ }^{65} \mathrm{Zn}\left(\mathrm{NO}_{3}\right)_{2}$ in target tissues.

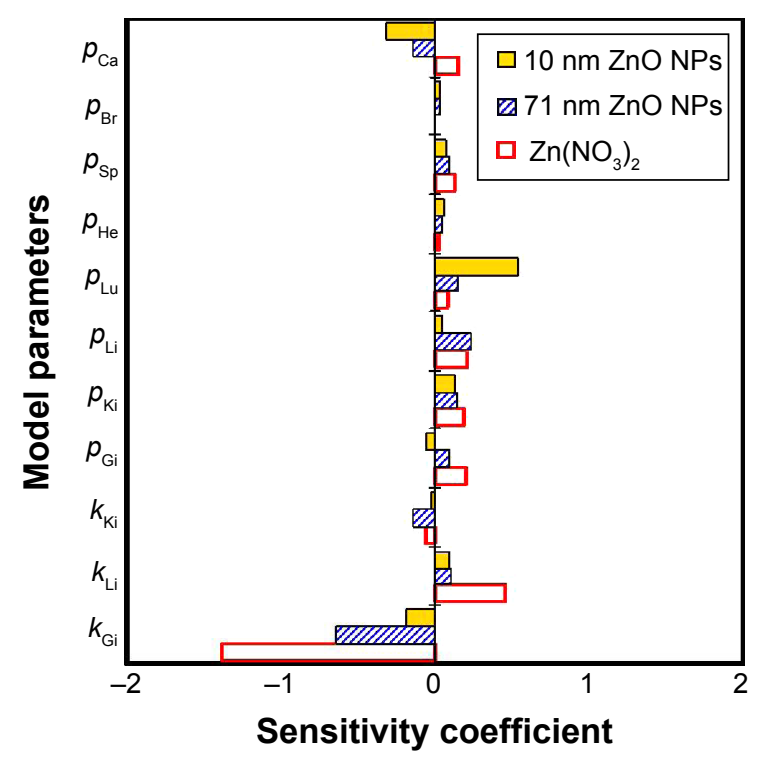

Figure 7 Sensitivity analysis of partition coefficients and excretion or elimination rates in the mice PBPK model.

Note: Right and left sides indicate the effects of increases in parameters on tissue concentration.

Abbreviations: PBPK, physiologically based pharmacokinetic; NP, nanoparticle; $p$, partition coefficient; $k$, excretion or elimination rate; Li, liver; Ki, kidney; Sp, spleen; Lu, lung; Br, brain; He, heart; Gl, gastrointestinal; $\mathrm{Ca}$, carcass.
We observed that the partition coefficient in the lung $\left(p_{\mathrm{Lu}}\right)$ was particularly high for $10 \mathrm{~nm}{ }^{65} \mathrm{ZnO} N$ Ps and that $p_{\mathrm{Lu}}$ was the most sensitive parameter of the biodistribution of $10 \mathrm{~nm}$ ${ }^{65} \mathrm{ZnO}$ NPs. This result might have been caused by the lung being the first organ with a reticuloendothelial system in contact with ${ }^{65} \mathrm{ZnO}$ NPs following intravenous injection. NPs are readily uptaken by phagocytic cells in the reticuloendothelial system. It is thus likely that alveolar macrophages in the lung would capture $10 \mathrm{~nm}{ }^{65} \mathrm{ZnO}$ NPs before translocating to the lymphatic tissue, and then trapped ${ }^{65} \mathrm{ZnO}$ NPs would be redistributed to other tissues over a longer duration. Our results support those hypotheses. ${ }^{24,25}$ However, at later time points, ${ }^{65} \mathrm{ZnO}$ NPs failed to accumulate in the lung and its partition coefficients decreased, suggesting that this mechanism in the lung might not be crucial in long-term biodistribution.

\section{Potential mechanisms for the biodistribution of NPs}

The potential mechanisms for the biodistribution of NPs are complicated. Several factors such as interactions with biological barriers and NP properties (composition, size, core properties, and surface modifications) have been shown to significantly influence the biodistribution and blood circulation half-life of circulating NPs. A study indicated that partition coefficients of tissues or blood might be influenced by factors including blood flow and the turnover rate of each tissue, tissue affinity, and lipid composition. ${ }^{26}$ An increased timedependent partition coefficient in the liver in mice exposed 


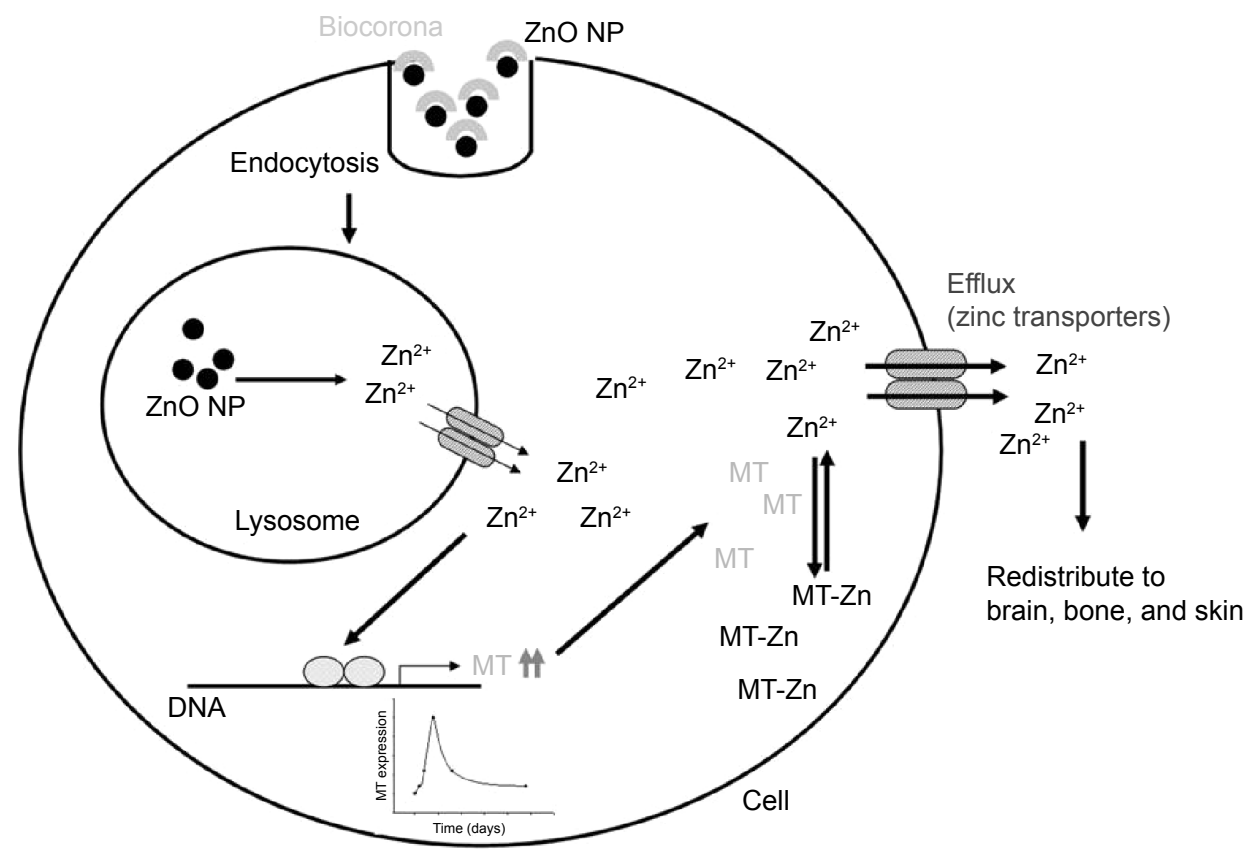

Figure 8 The proposed mechanisms for time-dependent partition coefficients in tissues. Abbreviation: NP, nanoparticle.

to polychlorinated biphenyls was identified. ${ }^{27} \mathrm{ZnO}$ NPs might be persistent in the approximately neutral surfactant fluid or cytosol, yet it is rapidly converted to $\mathrm{Zn}^{2+}$ when $\mathrm{ZnO}$ NPs internalized into the acid environment of the lysosome. ${ }^{17}$ From our previous studies and in vitro experiments, we proposed that $\mathrm{ZnO}$ NPs would decompose, release $\mathrm{Zn}^{2+}$, and upregulate MT protein after endocytosis (Figure 8). Sadhu and Gedamu reported that the upregulation of MT decreased dynamically with time after exposure to $\mathrm{Zn} .^{28} \mathrm{MT}$ binds to intracellular $\mathrm{Zn}^{2+}$ and increases their accumulation in cells (Figure 8). When MT protein decreases at later time points, $\mathrm{Zn}^{2+}$ ions are pumped out of the cells by the $\mathrm{Zn}$ transporter, reenter the circulation, and are subsequently stored in muscle and bone (referred to as carcass in this study). ${ }^{29,30}$ Therefore, the tissue partition coefficients of $\mathrm{ZnO}$ NPs might change time-dependently. Indeed, our results showed that the partition coefficients of $\mathrm{ZnO}$ NPs are dependent on time after exposure and might be affected by the decomposition of $\mathrm{ZnO}$ NPs (Figure 8). Also, the results have a good prediction when we replaced the partition coefficients and excretion or elimination rates of $10 \mathrm{~nm}$ and $71 \mathrm{~nm}$ $\mathrm{ZnO}$ NPs with that of $\mathrm{Zn}^{2+}$ after day 7 exposure.

Furthermore, NPs are reportedly readily uptaken by phagocytic cells in the liver, spleen, lung, and kidneys. ${ }^{31}$ Therefore, ZnO NPs quickly distribute to these organs within 24 hours of exposure. Proteins associated with the surfaces of NPs are recognized by macrophages and might modulate the translocation and redistribution of NPs from blood by organs with an reticuloendothelial system. ${ }^{32}$ In addition, the uptake and internalization of NPs in the brain might be facilitated by the formation of a biocorona, with plasma proteins on the surface of NPs, which allows for the crossing of the brain-blood barrier. ${ }^{33-35}$ Our data indicated that the relationship between time and partition coefficients in the brain and carcass differed from those in other tissues. Considering the unique biodistribution characteristics of $\mathrm{ZnO}$ NPs and $\mathrm{Zn}^{2+}$, we used the Hill equation to describe partitioning between blood and tissues in a time-dependent manner. The time-dependent partition coefficients fitted well with the measurement data and enabled the construction of our PBPK model for $\mathrm{ZnO}$ NPs.

\section{Implications}

We observed that the partition coefficients of the brain $\left(p_{\mathrm{Br}}\right)$ and carcass $\left(p_{\mathrm{Ca}}\right)$ increased time-dependently. This indicates that irrespective of phase and size, $\mathrm{ZnO} N P$ s and $\mathrm{Zn}\left(\mathrm{NO}_{3}\right)_{2}$ preferentially redistribute to the brain and carcass at later time points after exposure. With high partition coefficient, the $10 \mathrm{~nm} \mathrm{ZnO}$ NPs tend to redistribute and accumulate in the brain tissue. Although $p_{\mathrm{Br}}$ and $p_{\mathrm{Ca}}$ were relatively low following a single dose of the $\mathrm{Zn}$ compounds, multiple dosing for a long duration could potentially increase the accumulation of chemicals in the brain and carcass. $\mathrm{Zn}^{2+}$ ions are abundant in the brain and play crucial roles in learning and memory. ${ }^{36}$ However, Zn overdose can cause spatial reference memory deficit in animals. ${ }^{37}$ 
It has been identified that $\mathrm{ZnO}$ NPs have the potential ability to damage and kill neural stem cells in mice. ${ }^{38}$ Therefore, in future research, the cumulative and hazardous properties of $\mathrm{ZnO}$ NPs in the brain should be considered in long-term health assessments of brain damage and memory deficit.

The biodistribution of NPs is highly influenced by the cellular uptake of NPs through phagocytosis by the mononuclear phagocytic system. NPs can accumulate in phagocytic cells of specific organs including the liver, spleen, lung, kidney, and brain or redistribute to the lymphatic fluid. According to previous study, phagocytizing cells rapidly capture NPs until their saturation, constitute a major reservoir in richly perfused organs, including the spleen, liver, bone marrow, lungs, heart, and kidneys, and store $83 \%$ NPs in these organs 120 hours after injection. ${ }^{39}$ To more comprehensively understand the role of the mononuclear phagocytic system in the biodistribution of NPs, we will include mononuclear phagocytic system subcompartments in these organs when we construct PBPK models for NPs in future studies.

A report investigated and compared $\mathrm{ZnO} \mathrm{NP}$ and zinc chloride contents in the blood and observed that although $\mathrm{ZnO}$ NPs partly dissolve in gastric conditions (13\%-14\%), particles administered in various states produce different biodistribution profiles. ${ }^{40}$ Although studies have demonstrated that $\mathrm{ZnO}$ NPs can dissolve in tissues and release $\mathrm{Zn}^{2+}$ within hours, the metabolic mechanisms leading to the various biodistribution profiles of NPs and ions remain unclear and warrant further investigation. ${ }^{1,40}$ Given that the exposure doses and excretion or elimination rates of each tissue are known, a PBPK model suitable for transfer within various exposure routes (intravenous, inhalation, and oral) could be constructed. ${ }^{41,42}$

\section{Conclusion}

Despite certain data limitations, this study estimated and identified critical parameters influencing PBPK modeling in certain organs and tissues by using real-time mice exposure experiments. By considering the time-dependent partition coefficients and decomposition of ${ }^{65} \mathrm{ZnO}$ NPs into ${ }^{65} \mathrm{Zn}^{2+}$ after day 7 , we increased the predictability of the PBPK model for exposure experimental data. The general patterns of bioaccumulation and biodistribution of ${ }^{65} \mathrm{ZnO}$ NPs and ${ }^{65} \mathrm{Zn}\left(\mathrm{NO}_{3}\right)_{2}$ in mice were serviceably accurate.

In general, the tissue partition coefficients of ${ }^{65} \mathrm{ZnO}$ NPs were greater than those of ${ }^{65} \mathrm{Zn}\left(\mathrm{NO}_{3}\right)_{2}$, particularly the partition coefficient of $10 \mathrm{~nm}{ }^{65} \mathrm{ZnO}$ NPs in the lung. Sensitivity analysis revealed that $71 \mathrm{~nm}{ }^{65} \mathrm{ZnO} \mathrm{NPs}$ and ${ }^{65} \mathrm{Zn}\left(\mathrm{NO}_{3}\right)_{2}$ were sensitive to excretion or elimination rates in the liver and GI tract. We suggest caution against exposure to $\mathrm{ZnO}$ NPs $<10 \mathrm{~nm}$ because they tend to accumulate in the body for a relatively longer duration than $71 \mathrm{~nm}{ }^{65} \mathrm{ZnO}$ NPs and ${ }^{65} \mathrm{Zn}\left(\mathrm{NO}_{3}\right)_{2}$ do. Although the partition coefficient of the brain was relatively low, it time-dependently increased for ${ }^{65} \mathrm{ZnO} \mathrm{NPs}$ and ${ }^{65} \mathrm{Zn}\left(\mathrm{NO}_{3}\right)_{2}$. Hazardous exposure risk for the brain must thus be carefully considered. In this study, we established a potentially predictive dynamic model for NPs, which we will investigate more comprehensively in future studies.

\section{Acknowledgments}

This study was supported by a grant from the Ministry of Science and Technology of Taiwan (MOST 102-2932-I-400 -001-MY3). This work is a subproject of the collaborative project of the Seventh Framework Programme (FP7), funded by the European Union under project number 310715 (MODENP-TOX). The authors are grateful for the technical consultation provided by Miss Jui-Ping Li and Nai-Chun Huang of the Institute of Biomedical Engineering and Nanomedicine (BN-104-PP-27) and physicochemical characterization support provided by the Institute of Biomedical Engineering and Nanomedicine Service, NHRI, Zhunan, Taiwan.

\section{Author contributions}

All authors contributed toward data analysis, drafting and critically revising the paper, and agree to be accountable for all aspects of the work.

\section{Disclosure}

The authors report no conflicts of interest in this work.

\section{References}

1. Vandebriel RJ, De Jong WH. A review of mammalian toxicity of $\mathrm{ZnO}$ nanoparticles. Nanotechnol Sci Appl. 2012;5:61-71.

2. Adamcakova-Dodd A, Stebounova LV, Kim JS, et al. Toxicity assessment of zinc oxide nanoparticles using sub-acute and sub-chronic murine inhalation models. Part Fibre Toxicol. 2014;11:1-15.

3. Chuang HC, Juan HT, Chang CN, et al. Cardiopulmonary toxicity of pulmonary exposure to occupationally relevant zinc oxide nanoparticles. Nanotoxicology. 2014;8:593-604.

4. Akhtar MJ, Ahamed M, Kumar S, Khan MM, Ahmad J, Alrokayan SA. Zinc oxide nanoparticles selectively induce apoptosis in human cancer cells through reactive oxygen species. Int J Nanomedicine. 2012;7: 845-857.

5. Cao Z, Zhang Z, Wang F, Wang G. Synthesis and UV shielding properties of zinc oxide ultrafine particles modified with silica and trimethyl siloxane. Colloids Surf A Physicochem Eng Asp. 2009;340:161-167.

6. Rasmussen JW, Martinez E, Louka P, Wingett DG. Zinc oxide nanoparticles for selective destruction of tumor cells and potential for drug delivery applications. Expert Opin Drug Deliv. 2010;7:1062-1077.

7. Yeh TK, Chen JK, Lin CH, et al. Kinetics and tissue distribution of neutron-activated zinc oxide nanoparticles and zinc nitrate in mice: effects of size and particulate nature. Nanotechnology. 2012;23:085102. 
8. Krishnan K, Peyret T. Physiologically based toxicokinetic (PBTK) modeling in ecotoxicology. In: Devillers J, editor. Ecotoxicology Modeling. New York: Springer; 2009:145-175.

9. Peters SA. Physiologically-Based Pharmacokinetic (PBPK) Modeling and Simulations. New Jersey: John Wiley \& Sons, Inc; 2012.

10. Zhou JG, Zhao FY, Wang YL, Zhang Y, Yang L. Size-controlled synthesis of $\mathrm{ZnO}$ nanoparticles and their photoluminescence properties. J Lumin. 2007;122:195-197.

11. Talam S, Karumuri SR, Gunnam N. Synthesis, characterization, and spectroscopic properties of ZnO nanoparticles. ISRN Nanotechnol. 2012; 2012:372505.

12. Uysala I, Severcana F, Evisa Z. Characterization by Fourier transform infrared spectroscopy of hydroxyapatite co-droped with zinc and flouoride. Ceram Int. 2013;39:7727-7733.

13. Davies B, Morris T. Physiological parameters in laboratory animals and humans. Pharm Res. 1993;10:1093-1095.

14. Cheng HY, Jusko WJ. Mean residence time concepts for pharmacokinetic systems with nonlinear drug elimination described by the Michaelis-Menten equation. Pharm Res. 1988;5:156-164.

15. Rayer S. Population forecast accuracy: does the choice of summary measure of error matter. Popul Res Policy Rev. 2007;26:163-184.

16. Wilson T. The forecast accuracy of Australian bureau of statistics national population projections. J Popul Res. 2007;24:91-117.

17. Cho WS, Duffin R, Howie SE, et al. Progressive severe lung injury by zinc oxide nanoparticles; the role of $\mathrm{Zn}^{2+}$ dissolution inside lysosomes. Part Fibre Toxicol. 2011;8:1-27.

18. Brown RP, Delp MD, Lindstedt SL, Rhomberg LR, Beliles RP. Physiological parameter values for physiologically based pharmacokinetic models. Toxicol Ind Health. 1997;13:407-484.

19. Wang J, Liu Y, Jiao F, et al. Time-dependent translocation and potential impairment on central nervous system by intranasally instilled $\mathrm{TiO}_{2}$ nanoparticles. Toxicology. 2008;254:82-90.

20. Cho M, Cho WS, Choi M, et al. The impact of size on tissue distribution and elimination by single intravenous injection of silica nanoparticles. Toxicol Lett. 2009;189:177-183.

21. Lankveld DP, Oomen AG, Krystek P, et al. The kinetics of the tissue distribution of silver nanoparticles of different sizes. Biomaterials. 2010;31:8350-8361

22. Wenger Y, Schneider RJ 2nd, Reddy GR, Kopelman R, Jolliet O, Philbert MA. Tissue distribution and pharmacokinetics of stable polyacrylamide nanoparticles following intravenous injection in the rat. Toxicol Appl Pharmacol. 2011;251:181-190.

23. Dziendzikowska K, Gromadzka-Ostrowska J, Lankoff A, et al. Timedependent biodistribution and excretion of silver nanoparticles in male Wistar rats. J Appl Toxicol. 2012;32:920-928.

24. Park K, Park EJ, Chun IK, et al. Bioavailability and toxicokinetics of citrate-coated silver nanoparticles in rats. Arch Pharm Res. 2011;34: 153-158.

25. Takenaka S, Karg E, Roth C, et al. Pulmonary and systemaic distribution of inhaled ultrafine silver particles in rats. Environ Health Perspect. 2001;109(suppl 4):547-551.
26. Weijs L, Yang RS, Covaci A, Das K, Blust R. Physiologically based pharmacokinetic (PBPK) models for lifetime exposure to PCB 153 in male and female harbor porpoises (Phocoena phocoena): model development and evaluation. Environ Sci Technol. 2010;44:7023-7030.

27. Lee SK, Ou YC, Yang RSH. Comparison of pharmacokinetic interactions and physiologically based pharmacokinetic modeling of PCB 153 and PCB 126 in non-pregnant mice, lactating mice, and suckling pups. Toxicol Sci. 2002;65:26-34.

28. Sadhu C, Gedamu L. Metal-specific posttranscriptional control of human metallothionein genes. Mol Cell Biol. 1989;9:5738-5741.

29. Lichten LA, Cousins RJ. Mammalian zinc transporters: nutritional and physiologic regulation. Annu Rev Nutr. 2009;29:153-176.

30. King JC, Shames DM, Woodhouse LR. Zinc homeostasis in humans. J Nutr. 2000;130:1360S-1366S

31. Moghimi SM, Hunter AC, Murray JC. Long-circulating and target-specific nanoparticles: theory to practice. Pharmacol Rev. 2001;53:283-318.

32. Li SD, Huang L. Nanoparticles evading the reticuloendothelial system: role of the supported bilayer. Biochim Biophys Acta. 2009;1788: 2259-2266.

33. Lundqvist M, Stigler J, Elia G, Lynch I, Cedervall T, Dawson KA. Nanoparticle size and surface properties determine the protein corona with possible implications for biological impacts. Proc Natl Acad Sci US A. 2008;105:14265-14270.

34. Nel AE, Mädler L, Velegol D, et al. Understanding biophysicochemical interactions at the nano-bio interface. Nat Mater. 2009;8:543-557.

35. Wiley DT, Webster P, Gale A, Davis ME. Transcytosis and brain uptake of transferrin-containing nanoparticles by tuning avidity to transferrin receptor. Proc Natl Acad Sci U S A. 2013;110:8662-8667.

36. Frederickson CJ, Koh JY, Bush AI. The neurobiology of zinc in health and disease. Nat Rev Neurosci. 2005;6:449-462.

37. Flinn JM, Hunter D, Linkous DH, et al. Enhanced zinc consumption causes memory deficits and increased brain levels of zinc. Physiol Behav. 2005;83:793-803.

38. Deng X, Luan Q, Chen W, et al. Nanosized zinc oxide particles induce neural stem cell apoptosis. Nanotechnology. 2009;20:115101.

39. Li D, Johanson G, Emond C, Carlander U, Philbert M, Jolliet O. Physiologically based pharmacokinetic modeling of polyethylene glycol-coated polyacrylamide nanoparticles in rats. Nanotoxicology. 2014;8(S1):128-137.

40. Paek HJ, Lee YJ, Chung HE, et al. Modulation of the pharmacokinetics of zinc oxide nanoparticles and their fates in vivo. Nanoscale. 2013;5: 11416-11427.

41. Bachler G, von Goetz N, Hungerbühler K. A physiologically based pharmacokinetic model for ionic silver and silver nanoparticles. Int J Nanomedicine. 2013;8:3365-3382.

42. Li M, Reineke J. Mathematical modelling of nanoparticle biodistribution: extrapolation among intravenous, oral and pulmonary administration routes. Int J Nano Biomater. 2011;3:222-238. 


\section{Supplementary materials}
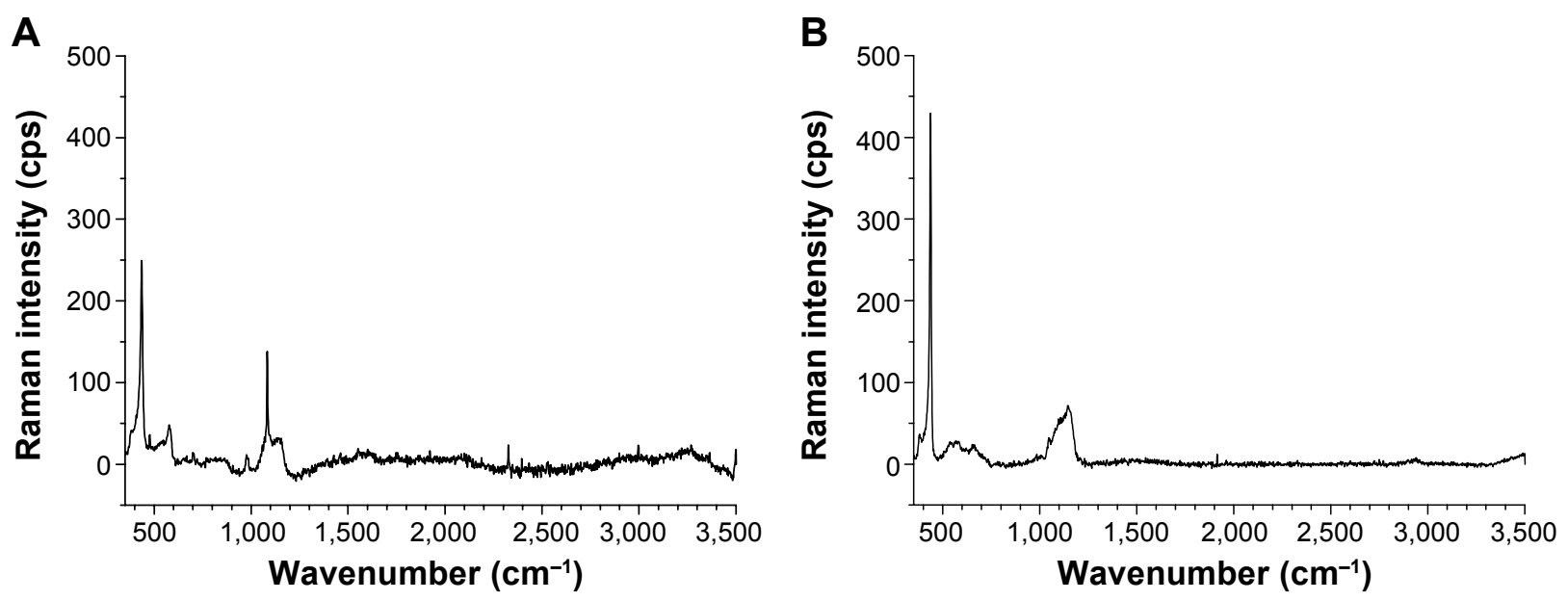

Figure SI Raman spectra of ZnO NPs.

Notes: Raman spectra of (A) $10 \mathrm{~nm}$ and (B) $71 \mathrm{~nm} \mathrm{ZnO}$ NPs.

Abbreviation: NP, nanoparticle.
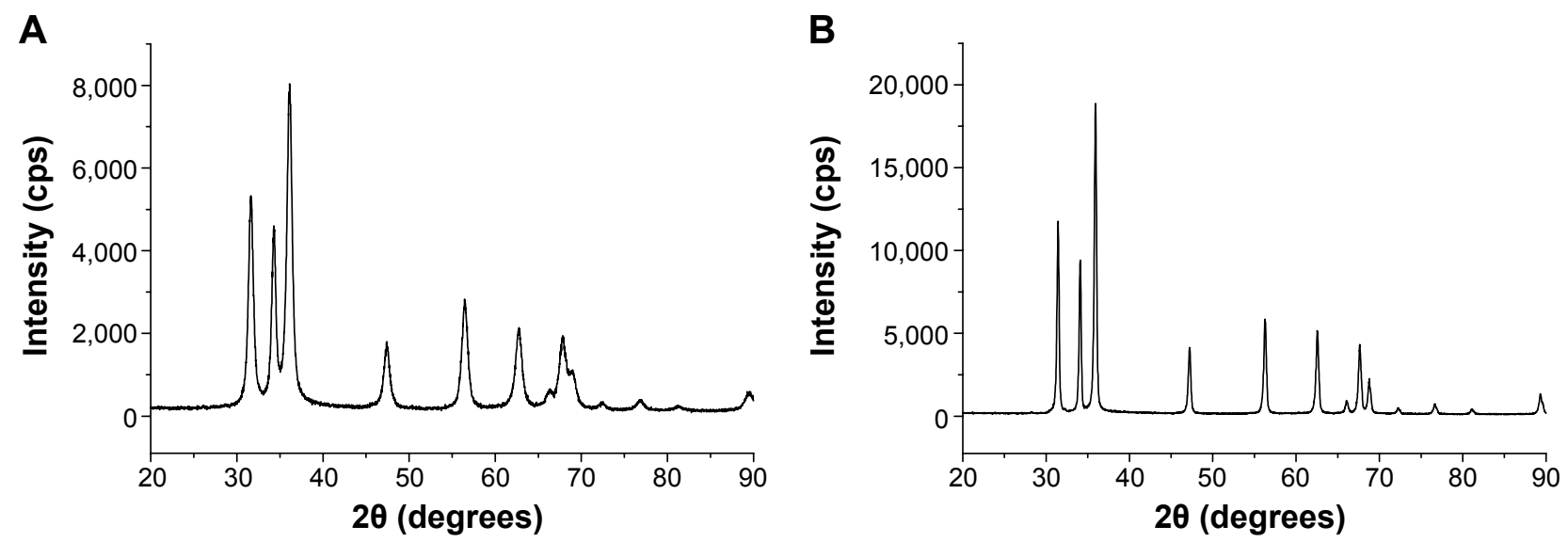

Figure S2 XRD patterns of $\mathrm{ZnO} N P s$.

Notes: XRD patterns of (A) $10 \mathrm{~nm}$ and (B) $71 \mathrm{~nm} \mathrm{ZnO} N P s$.

Abbreviations: XRD, X-ray diffraction; NP, nanoparticle. 


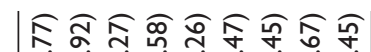

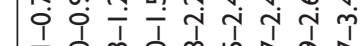

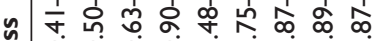
ป กิ 1 0 -

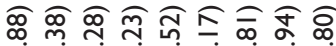
ก

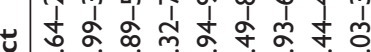
$= \pm d$ i vi

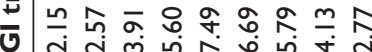

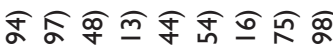
-j $\dot{\alpha} \dot{y}+\dot{y} m$

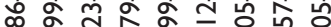

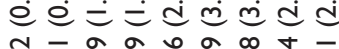
m

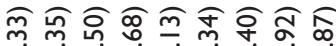
i o o

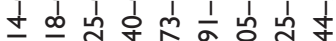
i c i c i c ปิ ก้

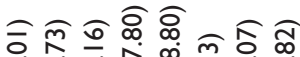

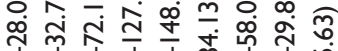
ֻ

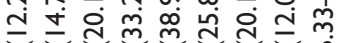

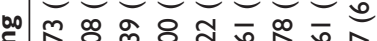

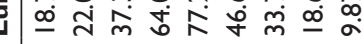

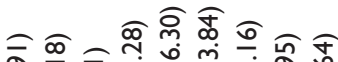

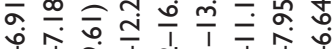
$\infty$ o $\infty$ กิ

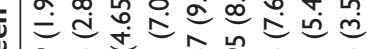

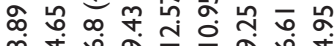

동

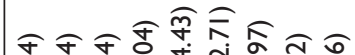
ن t 구의

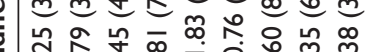

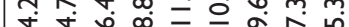

ह

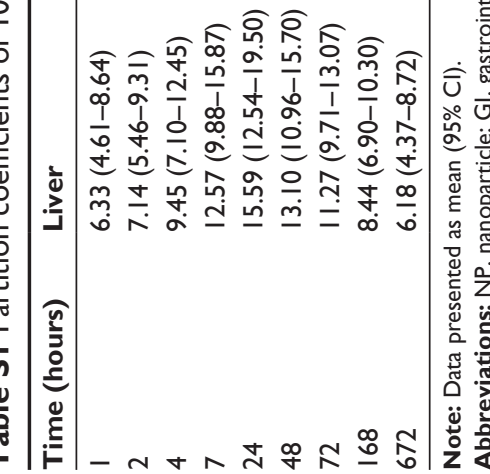

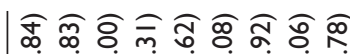

i i

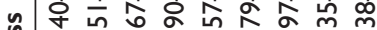

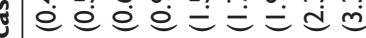

ป็

i 4 i

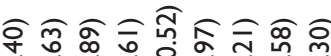

m

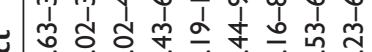

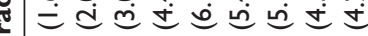

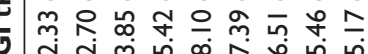

สิ์

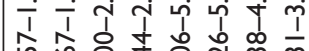

e e $=\dot{d} d \dot{d}$

ฮై

o $0 .-m m$ m

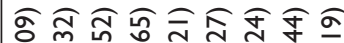

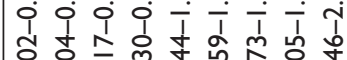

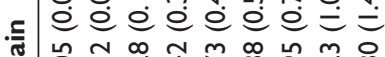

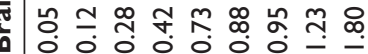

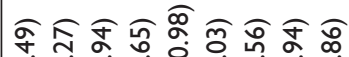

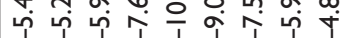

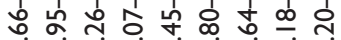

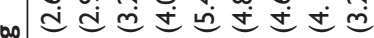

业

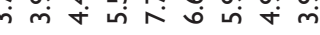

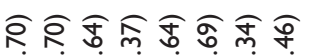

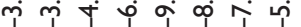

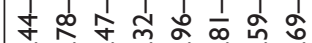

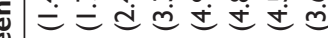

唇

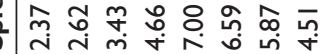

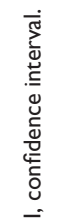

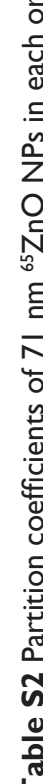

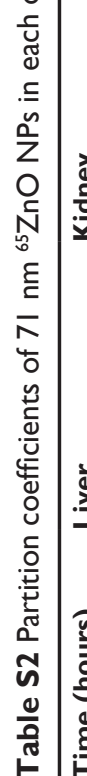

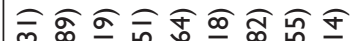

น ए एं वें

$\simeq$ 들

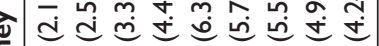

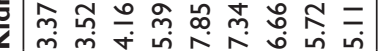

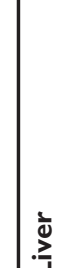

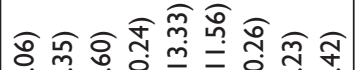

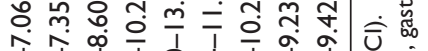

1)

迥

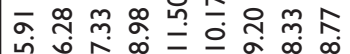

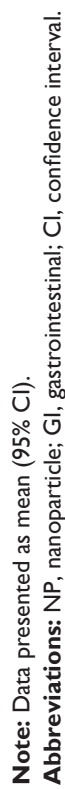

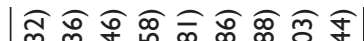

o o o o o o i - i.

น 는

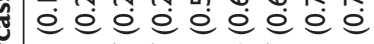

ग

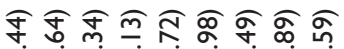

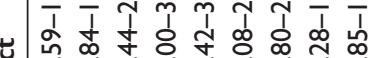

อ

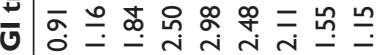

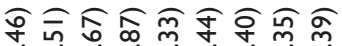

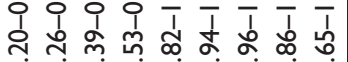

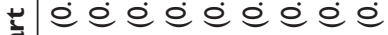

选

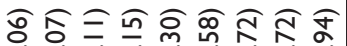
0 0 0 0 0 o o o

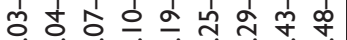

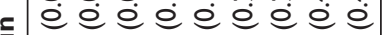

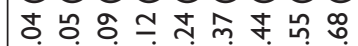

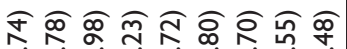

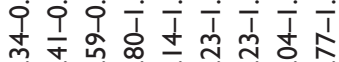

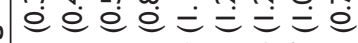

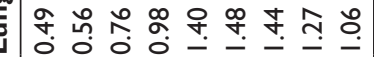

๙ o

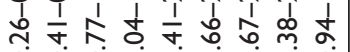

¿

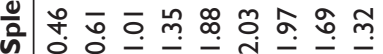

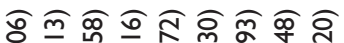
is

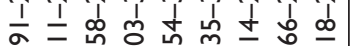
过空过过主

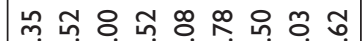
- i n m

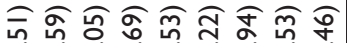
-

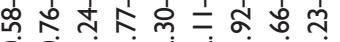

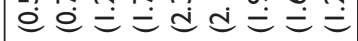

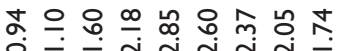

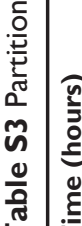

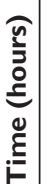


Table S4 Estimated excretion and elimination rates $\left(\mathrm{h}^{-1}\right)$ used in PBPK model for ${ }^{65} \mathrm{ZnO} \mathrm{NPs}$ and ${ }^{65} \mathrm{Zn}\left(\mathrm{NO}_{3}\right)_{2}$ in mice

\begin{tabular}{|c|c|c|c|}
\hline \multirow[t]{2}{*}{ Time (hours) } & \multicolumn{3}{|c|}{ Excretion and elimination rates $\left(h^{-1}\right)$} \\
\hline & 10 nm ${ }^{65} \mathrm{ZnO} \mathrm{NP}$ & $71 \mathrm{~nm}{ }^{65} \mathrm{ZnO} \mathrm{NP}$ & ${ }^{65} \mathrm{Zn}\left(\mathrm{NO}_{3}\right)_{2}$ \\
\hline \multicolumn{4}{|l|}{ Liver } \\
\hline 2 & NE & NE & NE \\
\hline 4 & $0.0438 \pm 0.00207$ & $0.0385 \pm 0.0234$ & $\mathrm{NE}$ \\
\hline 7 & $0.0309 \pm 0.0060$ & $0.0382 \pm 0.0052$ & $0.0325 \pm 0.0195$ \\
\hline 24 & $0.0291 \pm 0.0028$ & $0.0292 \pm 0.0019$ & $0.0306 \pm 0.0026$ \\
\hline 48 & $0.0239 \pm 0.0019$ & $0.0264 \pm 0.0016$ & $0.0255 \pm 0.0020$ \\
\hline 72 & $0.0207 \pm 0.0015$ & $0.0240 \pm 0.0014$ & $0.0216 \pm 0.0017$ \\
\hline 168 & $0.00193 \pm 0.0015$ & $0.0234 \pm 0.0014$ & $0.0203 \pm 0.0017$ \\
\hline 672 & $0.0193 \pm 0.0015$ & $0.0234 \pm 0.0014$ & $0.0203 \pm 0.0016$ \\
\hline \multicolumn{4}{|l|}{ Kidney } \\
\hline 2 & $0.0618 \pm 0.0492$ & $0.076 \mathrm{I} \pm 0.0838$ & $0.1218 \pm 0.0537$ \\
\hline 4 & $0.0287 \pm 0.0790$ & $\mathrm{NE}$ & $\mathrm{NE}$ \\
\hline 7 & $\mathrm{NE}$ & $\mathrm{NE}$ & $0.0614 \pm 0.0066$ \\
\hline 24 & $0.0166 \pm 0.0020$ & $0.0162 \pm 0.0014$ & $0.0389 \pm 0.004 \mathrm{I}$ \\
\hline 48 & $0.0131 \pm 0.001 \mathrm{I}$ & $0.0154 \pm 0.0010$ & $0.0309 \pm 0.0031$ \\
\hline 72 & $0.0122 \pm 0.0008$ & $0.0150 \pm 0.0008$ & $0.0260 \pm 0.0023$ \\
\hline 168 & $0.0106 \pm 0.0007$ & $0.0146 \pm 0.0007$ & $0.0253 \pm 0.0022$ \\
\hline 672 & $0.0106 \pm 0.0007$ & $0.0146 \pm 0.0007$ & $0.0252 \pm 0.0021$ \\
\hline \multicolumn{4}{|l|}{ Gl tract } \\
\hline 2 & $\mathrm{NE}$ & $\mathrm{NE}$ & $\mathrm{NE}$ \\
\hline 4 & NE & $\mathrm{NE}$ & $\mathrm{NE}$ \\
\hline 7 & $0.032 I \pm 0.0293$ & $0.0400 \pm 0.0042$ & $0.0629 \pm 0.0233$ \\
\hline 24 & $0.0238 \pm 0.003 \mid$ & $0.0260 \pm 0.0024$ & $0.0508 \pm 0.0038$ \\
\hline 48 & $0.0197 \pm 0.0018$ & $0.024 I \pm 0.0018$ & $0.0445 \pm 0.0034$ \\
\hline 72 & $0.0179 \pm 0.0013$ & $0.0229 \pm 0.0015$ & $0.04|5 \pm 0.003|$ \\
\hline 168 & $0.0168 \pm 0.0012$ & $0.0226 \pm 0.0014$ & $0.04 \mid 4 \pm 0.0030$ \\
\hline 672 & $0.0168 \pm 0.0012$ & $0.0226 \pm 0.0014$ & $0.0414 \pm 0.0029$ \\
\hline
\end{tabular}

Note: Data presented as mean \pm standard error.

Abbreviations: GI, gastrointestinal; NE, no estimates; NP, nanoparticle; PBPK, physiologically based pharmacokinetic.

\section{Publish your work in this journal}

The International Journal of Nanomedicine is an international, peerreviewed journal focusing on the application of nanotechnology in diagnostics, therapeutics, and drug delivery systems throughout the biomedical field. This journal is indexed on PubMed Central, MedLine, CAS, SciSearch $®$, Current Contents ${ }^{\circledR} /$ Clinical Medicine,
Journal Citation Reports/Science Edition, EMBase, Scopus and the Elsevier Bibliographic databases. The manuscript management system is completely online and includes a very quick and fair peer-review system, which is all easy to use. Visit http://www.dovepress.com/ testimonials.php to read real quotes from published authors. 